\title{
Investigating the molecular underpinnings underlying morphology and changes in carbon partitioning during tension wood formation in Eucalyptus
}

\author{
Eshchar Mizrachi ${ }^{1}$, Victoria J. Maloney ${ }^{2}$, Janine Silberbauer ${ }^{1}$, Charles A. Hefer ${ }^{3}$, Dave K. Berger ${ }^{4}$, \\ Shawn D. Mansfield ${ }^{2}$ and Alexander A. Myburg ${ }^{1}$
}

\begin{abstract}
${ }^{1}$ Department of Genetics, Forestry and Agricultural Biotechnology Institute (FABI), University of Pretoria, Private bag X20, Pretoria 0028, South Africa; ${ }^{2}$ Department of Wood Science, University of British Columbia, 4030-2424 Main Mall, Vancouver, BC V6T 1Z4, Canada; ${ }^{3}$ Bioinformatics and Computational Biology Unit, Department of Biochemistry, University of Pretoria, Private Bag X20, Pretoria 0028, South Africa; ${ }^{4}$ Department of Plant Science, Forestry and Agricultural Biotechnology Institute (FABI), University of Pretoria, Pretoria 0002, South Africa
\end{abstract}

Author for correspondence:

Alexander A. Myburg

Tel: +27124204945

Email: zander.myburg@up.ac.za

Key words: cellulose, Eucalyptus, hemicellulose, lignin, RNA-seq, tension wood, transcriptome, xylan.

\section{Summary}

- Tension wood has distinct physical and chemical properties, including altered fibre properties, cell wall composition and ultrastructure. It serves as a good system for investigating the genetic regulation of secondary cell wall biosynthesis and wood formation. The reference genome sequence for Eucalyptus grandis allows investigation of the global transcriptional reprogramming that accompanies tension wood formation in this global wood fibre crop.

- We report the first comprehensive analysis of physicochemical wood property changes in tension wood of Eucalyptus measured in a hybrid (E. grandis $\times$ Eucalyptus urophylla) clone, as well as genome-wide gene expression changes in xylem tissues 3 wk post-induction using RNA sequencing.

- We found that Eucalyptus tension wood in field-grown trees is characterized by an increase in cellulose, a reduction in lignin, xylose and mannose, and a marked increase in galactose. Gene expression profiling in tension wood-forming tissue showed corresponding down-regulation of monolignol biosynthetic genes, and differential expression of several carbohydrate active enzymes.

- We conclude that alterations of cell wall traits induced by tension wood formation in Eucalyptus are a consequence of a combination of down-regulation of lignin biosynthesis and hemicellulose remodelling, rather than the often proposed up-regulation of the cellulose biosynthetic pathway.

\section{Introduction}

Tension wood formation is a dicot-specific physiological reaction to mechanical or gravimetric stress on the tree. The biology of tension wood is still not fully understood, but evidence suggests that transcriptional and metabolic reprogramming contributes significantly to the early induction and establishment of the developmental programme and the later stable formation of wood with altered chemical composition and ultrastructure. As tension wood formation is associated with a trend towards decreased lignin and increased cell wall polysaccharides (Al-Haddad et al., 2013), it presents a relevant model in which to investigate the molecular underpinnings of carbon allocation and carbohydrate deposition in wood. While most genome-wide gene expression and wood physicochemical analyses have thus far been performed in Populus species and hybrids (Andersson-Gunnerås et al., 2006), the availability of a genome from a second forest tree species, Eucalyptus grandis (Myburg et al., 2014), facilitates comparative studies to better understand the biology of tension wood formation in a woody plant that has evolved independently from other sequenced plants for $>100$ million yr, with a large part of this independent evolution occurring in complete isolation on the Australian continent.

Tension wood possesses distinct physical and chemical properties. Reported physical changes in tension wood include longer vessels (Jourez et al., 2001), longer and thinner fibres (Yoshizawa et al., 2000; Jourez et al., 2001) - possessing a thicker cell wall and smaller lumen - and a higher fibre: vessel ratio compared with normal or opposite wood (Jourez et al., 2001; Ruelle et al., 2006). The vessels and fibres are also typically more compact in tension wood, such that the middle lamellae possess a smaller surface area (Bowling \& Vaughn, 2008). Within the secondary cell walls (SCWs) of tension wood fibres, there are marked differences in cellulose properties. Typically, $\boldsymbol{\alpha}$-cellulose is relatively increased in tension wood (Côté et al., 1969; Okuyama et al., 1994; Yoshizawa etal., 2000), and the cellulose is more 
crystalline (Okuyama et al., 1994; Muller et al., 2006) and has a marked decrease in microfibril angle (MFA; Okuyama etal., 1994; Washusen etal., 2005; Ruelle et al., 2006, 2010; Clair et al., 2011).

In some cases, the traditional three-layered $\left(S_{1}, S_{2}\right.$ and $\left.S_{3}\right)$ secondary cell wall layers are often reported to be partially replaced by a gelatinous layer (G-layer) in tension wood, although this is not obligatory, and varies between and within angiosperm species (Washusen etal., 2003; Clair etal., 2006b; Qiu etal., 2008; Ruelle et al., 2010). It is also debatable whether the G-layer is the causal agent of generating the tension (Okuyama etal., 1994; Yamamoto, 2004; Fang et al., 2007, 2008; Goswami et al., 2008) or a physiological byproduct of xylem reprogramming in some species (Washusen et al., 2003; Clair et al., 2006a; Qiu et al., 2008). However, in all cases tension wood is characterized by a relative increase in cell wall glucose in the form of cellulose, a decrease in lignin (Bentum et al., 1969; Okuyama etal., 1994; Aoyama et al., 2001; Yoshida et al., 2002), and an increase in the syringyl:guaiacyl ( $\mathrm{S}: \mathrm{G})$ lignin monomer ratio (Aoyama et al., 2001; Yoshida et al., 2002; Joseleau et al., 2004). Similarly, the hemicellulose composition changes, and may be variable, especially with the presence/absence of a G-layer. Previous reports have highlighted the putative roles of xyloglucan (Nishikubo et al., 2007; Mellerowicz et al., 2008; Baba et al., 2009), pectinacious compounds (Andersson-Gunnerås et al., 2006; Goulao et al., 2011) such as rhamnogalacturonan I (RG I) (Bowling \& Vaughn, 2008) and other galactose-containing polysaccharides such as those found in arabinogalactan proteins (AGPs) (Lafarguette et al., 2004; Andersson-Gunnerås et al., 2006; Bowling \& Vaughn, 2008) in generating or facilitating tension wood formation. The orientation of cellulose microfibrils has been suggested to be influenced by galactan, which (either as a component of AGPs or as high-molecular-weight galactan) has been implicated in cellulose orientation during $\mathrm{S}_{2}$ deposition in other fibres with a G-layer-rich physiology, such as flax phloem fibres (Gorshkova \& Morvan, 2006; Roach et al., 2011).

The most detailed study of the physiological and molecular responses to tension wood to date has been performed by Andersson-Gunnerås etal. (2006), who examined transcriptional and metabolomic responses of G-layer-forming tension wood in $P$. tremula $3 \mathrm{wk}$ post tension wood induction. Primarily focusing on carbohydrate metabolism, these authors showed that, while the expression of cellulose synthase genes was not necessarily affected at the transcriptional level, the differential regulation of genes belonging to several key pathways was indicative of the change in carbon allocation favouring biosynthesis of cellulose over other cell wall moieties. For example, significant decreases in GDP sugar channelling to mannan biosynthesis and the pentose phosphate pathway were observed (Andersson-Gunnerås et al., 2006).

Several studies have also consistently found evidence of key hormone signalling pathways affected in tension wood-forming tissue, such as the activation of ethylene-mediated pathways (Andersson-Gunnerås et al., 2003, 2006; Vahala et al., 2013). Ethylene is known to be an inducer of cambial growth (Love et al., 2009), and has been shown in Zinnia elegans to be mass- produced in late-maturing tracheary elements (TEs) and diffuse in a paracrine fashion (i.e. influencing any immediately surrounding cells) to modulate additional TE differentiation from the cambium, coordinating both axial and radial vascular development (Pesquet \& Tuominen, 2011). Auxin maintains cambial initials in an undifferentiated form, while polar auxin transport and localized auxin suppression are associated with cambial differentiation (Moyle etal., 2002; Ko etal., 2004; Baba etal., 2011). Gibberellins have also been shown to act synergistically with auxin to promote cambial differentiation and fibre elongation (Little \& Savidge, 1987), and the production of gibberellic acid (GA) and auxins induces similar responses at the transcriptional level (Björklund et al., 2007). The synergistic mechanism is probably governed by the influence of GA on the polar transport of auxin (reviewed in Elo etal., 2009). Several hormones, and particularly GA, have also been linked to cortical microtubule arrangement during cellulose deposition, indirectly influencing cellulose properties (Lloyd, 2011). For example, jasmonic acid (JA) signalling has been linked to cells under tension, showing up-regulation of the mechano-inducible JASMONATE ZIMdomain $10(J A Z 10)$ gene in the interfascicular fibres of Arabidopsis thaliana (Sehr et al., 2010). JA signalling was shown to stimulate secondary growth of cambial initials (Sehr et al., 2010), although this aspect has not yet been adequately studied in a woody species.

Despite extensive research on tension wood formation, much has not been resolved concerning the physicochemical changes in tension wood in Eucalyptus, and it is not known whether the changes in tension wood would result in a similar phenotype to that observed in other woody angiosperms, such as Populus. Previously, Paux et al. (2005) and Qiu et al. (2008) reported on variation in the gene expression profiles of 231 genes on a 4900probe microarray during tension wood formation in Eucalyptus. More recently, a focused study of 38 hemicellulose- and pectinmodifying candidate genes was also performed in Eucalyptus globulus (Goulao etal., 2011). Considering the extent of gene duplication and the roles of potential paralogues, it is crucial to obtain a transcriptome-wide view of the transcriptional response, as expression profiling of individual paralogues may be misleading. As xylogenesis is known to be regulated to a large extent at a transcriptional level, it would be interesting to see if tension wood formation results in similar transcriptional reprogramming that explains the changes in phenotype, and may highlight important genes or regulatory elements that have not previously been identified. This could be beneficial to industrial applications such as pulp, paper, timber and biofuel production, as they would offer targets for selection in breeding programmes or candidates for genetic manipulation.

In this study, we aimed to investigate the physical effects observed in mature tension wood-forming tissue of a widely grown hybrid Eucalyptus genotype (Eucalyptus grandis $\times$ Eucalyptus urophylla). We further aimed to provide a detailed, whole-transcriptome characterization of Eucalyptus tension wood-forming tissue at $3 \mathrm{wk}$ post induction by mRNA sequencing to investigate the transcriptional reprogramming that occurs during stable tension wood formation. We hypothesized that 
the transcriptional response in Eucalyptus should reflect the rapid differentiation of longer, thinner fibre cells, which should be accompanied by evidence of a flux of auxin-mediated pathways and the up-regulation of ethylene- and GA-mediated pathways, as well as an increase in pectic degradation, rapid cell elongation and altered programmed cell death, to reflect this fibre phenotype.

\section{Materials and Methods}

\section{Sampling for wood property analysis}

To characterize the physicochemical properties of tension wood in Eucalyptus trees and to obtain enough tissue for wood chemistry analysis, we collected basal sections of naturally leaning branches from five different ramets of the same 3-4 yr-old $\mathrm{F}_{1}$ Eucalyptus grandis (Hill ex Maiden) $\times$ Eucalyptus urophylla (S.T. Blake) hybrid clone (GUSAP1; Sappi Forest Research, KwaMbonambi, South Africa; Supporting Information Fig. S1). A section of the leaning stems of each of the five trees was analysed where the angle was $45^{\circ}$ in relation to the main trunk of the tree. For each tree, sections were compared between the side closer to the main trunk (top of the branch; tension wood-forming) and the side opposite to that (opposite wood-forming). This provided a sample of woody material produced by stable tension wood formation (i.e. not recently induced).

\section{Klason lignin determination}

Wood was ground in a Wiley mill (Thomas Scientific, Philadelphia, PA, USA) to pass a $0.4-\mathrm{mm}$ screen (40 mesh) and Soxhlet extracted overnight in hot acetone to remove extractives. Lignin and carbohydrate contents were determined with a modified Klason (Coleman etal., 2009) method in which extracted ground stem tissue $(100 \mathrm{mg})$ was treated with $3 \mathrm{ml}$ of $72 \%$ $\mathrm{H}_{2} \mathrm{SO}_{4}$ and stirred every $10 \mathrm{~min}$ for $2 \mathrm{~h}$. Samples were then diluted with $112 \mathrm{ml}$ of deionized water and autoclaved for $1 \mathrm{~h}$ at $121^{\circ} \mathrm{C}$. The acid-insoluble lignin fraction was determined gravimetrically by filtration through a pre-weighed medium-coarseness sintered-glass crucible, while the acid-soluble lignin component was determined spectrophotometrically by absorbance at $205 \mathrm{~nm}$. Carbohydrate contents were determined using an anion exchange high-performance liquid chromatograph (Dx-600; Dionex, Sunnyvale, CA, USA) equipped with an ion exchange PA1 (Dionex) column, a pulsed amperometric detector with a gold electrode, and a SpectraAS3500 auto injector (Spectra-Physics, Santa Clara, CA, USA).

\section{$\alpha$-cellulose content determination}

The holocellulose content was determined using a modified version of the method of Browning (1967). Briefly, $200 \mathrm{mg}$ of extracted ground wood was de-lignified by adding $3.5 \mathrm{ml}$ of buffer solution $\left(60 \mathrm{ml}\right.$ of glacial acetic acid $\left.+1.3 \mathrm{~g} \mathrm{NaOH} \mathrm{l}^{-1}\right)$ and $1.5 \mathrm{ml}$ of $20 \%$ sodium chlorite solution $\left(20 \mathrm{~g} \mathrm{NaClO}_{2}\right.$ in $80 \mathrm{ml}$ of distilled water) then gently shaken at $50^{\circ} \mathrm{C}$ overnight
(14-16 h). The following day the reaction was quenched by placing it into an ice bath and incubating it at $4^{\circ} \mathrm{C}$ for several hours before the reaction solution was removed and a second reaction was performed overnight. Finally, the reacted wood meal was transferred to a pre-weighed coarse sintered-glass crucible and washed twice with $50 \mathrm{ml}$ of $1 \%$ glacial acetic acid followed by a single wash with $10 \mathrm{ml}$ of acetone under suction. The resulting holocellulose was permitted to dry in a $50^{\circ} \mathrm{C}$ oven overnight and the percentage of total extracted ground wood was determined gravimetrically. The $\alpha$-cellulose content was then determined by extracting $80 \mathrm{mg}$ of the oven-dried holocellulose with $4 \mathrm{ml}$ of $17.5 \%$ sodium hydroxide for $30 \mathrm{~min}$ at room temperature then adding $4 \mathrm{ml}$ of water, stirring for $1 \mathrm{~min}$ and leaving it to react for another $29 \mathrm{~min}$. The reaction solution was then filtered through a pre-weighed coarse sintered-glass crucible, washed with deionized water $(3 \times 50 \mathrm{ml})$, soaked in $1.0 \mathrm{M}$ acetic acid for $5 \mathrm{~min}$ and washed again with deionized water $(3 \times 50 \mathrm{ml})$. Finally, the samples were dried at $50^{\circ} \mathrm{C}$ overnight and the percentage of total holocellulose was determined gravimetrically (Yokoyama et al., 2002).

\section{Microfibril angle determination}

Microfibril angle estimates were generated by X-ray diffraction (Ukrainetz etal., 2008). The 002 diffraction spectra were screened for T-value distribution and symmetry on a Bruker D8 discover X-ray diffraction unit (Bruker-ASX, Madison WI, USA) equipped with an general area array detector (GADDS; Bruker). Wide-angle diffraction was used in the transmission mode, and the measurements were performed with $\mathrm{CuK \alpha} 1$ radiation $(\lambda=1.54 \AA)$. The X-ray source was fitted with a 0.5 -mm collimator, and the scattered photons were collected by a GADDS detector. Both the X-ray source and detector were set to theta $=0^{\circ}$.

\section{Calcofluor staining for cellulose}

Samples were radially cut into $20-\mu \mathrm{m}$ cross-sections using a Leica SM2000r hand sliding microtome (Leica Microsystems, Wetzlar, Germany) and stored in $\mathrm{dH}_{2} \mathrm{O}$ until needed. Sections were treated with $0.01 \%$ calcofluor white for $3 \mathrm{~min}$, then washed three times to remove excess stain (Falconer \& Seagull, 1985). All sections were mounted onto glass slides and examined with a Leica DRM microscope (Leica Microsystems) fitted with epifluorescence optics. Photographs were taken with a QICAM camera (QImaging, Surrey, Canada) and OpenLab software (PerkinElmer Inc., Waltham, MA, USA). Images were visualized and analysed using IMAGEJ software (Abràmoff et al., 2004).

Tension wood induction and sampling of differentiating xylem for transcriptome analysis

A tree bending trial was conducted in a clonal field trial near KwaMbonambi in Northern Kwazulu-Natal, South Africa (Sappi Forest Research) to induce tension wood formation in ramets of the same F1 clone (GUSAP1) as used for wood property analyses. 
The main stems of three 18-month-old ramets of the clone were bent at an angle of $c .45^{\circ}$ for $3 \mathrm{wk}$ in the field. To avoid temporal variation in gene expression, sampling of all replicates was completed within $3 \mathrm{~h}$ around noon on the same day under the same environmental conditions. Differentiating xylem tissue was isolated from the section of the stem bent at $45^{\circ}(c .50 \mathrm{~cm})$, removing the bark and immediately scraping the exposed outer differentiating layers of xylem cells $4-5 \mathrm{~mm}$ deep. For each bent stem, the upper (tension wood) side was scraped. Differentiating xylem was collected from the corresponding location (height from the base) on three unbent controls. All samples were immediately frozen in liquid nitrogen and stored at $-80^{\circ} \mathrm{C}$.

\section{RNA isolation, sequencing and analysis}

Total RNA was isolated from the xylem samples using a cetyl trimethylammonium bromide (CTAB)-based method (Chang et al., 1993). Frozen wood samples were ground to a fine powder in liquid nitrogen using a high-speed grinder (IKA-Werke, Staufen, Germany). Fifteen millilitres of extraction buffer was mixed with $3 \mathrm{~g}$ of ground tissue. RNA quantity and purity were assessed using a Nanodrop spectrophotometer (Nanodrop Technologies ND 1000, Wilmington, DE, USA), Agilent Bioanalyser 2100 RNA 6000 pico total RNA kits (Agilent Technologies, Santa Clara, CA, USA) and 1.5\% RNase-free agarose gels. To qualify for mRNA-Seq library preparation, all RNA samples had to have RNA integrity (RIN) numbers (Schroeder et al., 2006) of 8.0 or higher. In addition, the samples were tested for DNA contamination using an intron-spanning PCR. RNA from three biological replicates each of tension wood and upright control samples was sequenced (paired-end, $80 \mathrm{bp}-80 \mathrm{bp}$ ) and mapped to the E. grandis genome using ТОРНАТ (Trapnell et al., 2009) version 1.3.1, with the JGI V.02 gene models as a reference (www.phytozome.net). Total mapped reads varied from c. 8 million to 20 million between samples (Supporting Information Table S1). Expression levels (fragments per kilobase of coding sequence per million mapped fragments (FPKM)) were calculated differentially expressed genes were identified using the CufFLINKS and
CUFFDIFF packages, version 1.0.3 (Trapnell et al., 2010). Aligned reads have been submitted to the Sequence Read Archive (SRA) (Leinonen et al., 2010) under project code SRP047282.

\section{Results}

\section{Physicochemical changes of tension wood in Eucalyptus}

We assessed changes in wood properties in naturally occurring tension wood derived from plantation-grown trees. To do this we collected tension and opposite wood from leaning basal side branches of five different ramets of an E. grandis $\times$ E. urophylla clone (GUSAP1; Sappi Forest Research; Fig. S1). Physical, chemical and ultrastructural characteristics of the tension wood and opposite wood were measured and compared (Table 1). In accordance with the individually quantified fibre characteristics, a marked difference in cell wall thickness between tension wood and opposite wood was observable by microscopy (Figs 1, S2). In the tension wood, fibres were on average $20 \%$ longer and showed a $40 \%$ increase in fibre coarseness. Fibre width was not significantly changed, but the secondary cell walls were thicker, consistent with the coarseness estimates. The fibre:vessel ratio was also higher in the tension wood (vessel density was 33\% lower in tension wood), while vessel length and width were not significantly different.

In addition to the physical wood measurements, chemical analysis of the wood was performed to quantify changes in cellulose properties (Table 2), as well as lignin and total cell wall carbohydrate differences compared with opposite wood (Table 3). Although wood density and holocellulose (total polysaccharide) content were not different between tension and opposite wood, there was a significant increase in relative glucose content $(c .6 \mathrm{mg}$ $100 \mathrm{mg}^{-1}$ or a $16 \%$ relative increase) in the tension wood. This was mainly attributable to a relative increase in cellulose, as reflected in the significant increase in the $\alpha$-cellulose content of the tension wood (Table 2). Consistent with previous tension wood studies, we also found a lower MFA in the tension wood $(20 \%$ decrease). The hemicellulose composition was also

Table 1 Fibre and vessel properties in tension and opposite wood of five ramets of Eucalyptus grandis $\times$ Eucalyptus urophylla $\mathrm{F}_{1}$ hybrid clone GUSAP1

\begin{tabular}{llllllr}
\hline Sample & $\begin{array}{l}\text { Fibre length } \\
(\mathrm{mm})\end{array}$ & $\begin{array}{l}\text { Fibre width } \\
(\mu \mathrm{m})\end{array}$ & $\begin{array}{l}\text { Fibre coarseness } \\
\left(\mathrm{mg} \mathrm{m}^{-1}\right)\end{array}$ & $\begin{array}{l}\text { Vessel area } \\
\left(\mathrm{mm}^{2}\right)\end{array}$ & $\begin{array}{l}\text { Vessel length } \\
(\mathrm{mm})\end{array}$ & $\begin{array}{l}\text { Vessel width } \\
(\mu \mathrm{m})\end{array}$ \\
\hline Opposite wood 1 & 0.78 & 18.50 & 0.03 & 0.07 & 0.57 & 118.30 \\
Opposite wood 2 & 0.69 & 19.20 & 0.04 & 0.06 & 0.54 & 107.20 \\
Opposite wood 3 & 0.62 & 19.10 & 0.05 & 0.06 & 0.51 & 112.70 \\
Opposite wood 4 & 0.77 & 19.20 & 0.06 & 0.06 & 0.54 & 114.20 \\
Opposite wood 5 & 0.70 & 18.20 & 0.06 & 0.05 & 0.49 & 105.40 \\
Tension wood 1 & 0.88 & 17.90 & 0.06 & 0.07 & 0.56 & 118.30 \\
Tension wood 2 & 0.75 & 19.20 & 0.05 & 0.07 & 0.57 & 121.30 \\
Tension wood 3 & 0.85 & 17.40 & 0.06 & 0.06 & 0.57 & 109 \\
Tension wood 4 & 0.88 & 18.40 & 0.06 & 0.07 & 0.56 & 109.10 \\
Tension wood 5 & 0.87 & 18.60 & 0.06 & 0.07 & 0.55 & 124.50 \\
Opposite wood (mean \pm SD) & $0.70 \pm 0.06$ & $18.84 \pm 0.46$ & $0.05 \pm 0.01$ & $0.06 \pm 0.01$ & $0.53 \pm 0.03$ & 121.40 \\
Tension wood (mean \pm SD) & $0.85 \pm 0.05 * *$ & $18.30 \pm 0.69$ & $0.06 \pm 0.00 *$ & $0.07 \pm 0.00$ & $0.56 \pm 0.01$ & $11.56 \pm 5.26$ \\
\hline
\end{tabular}

Vessels $\mathrm{m}^{-1}$ indicates the density of vessels, calculated as the number $(n)$ of observed vessels. Paired, two-tailed $t$-test: $*, P \leq 0.05 ; * *, P \leq 0.01$. 

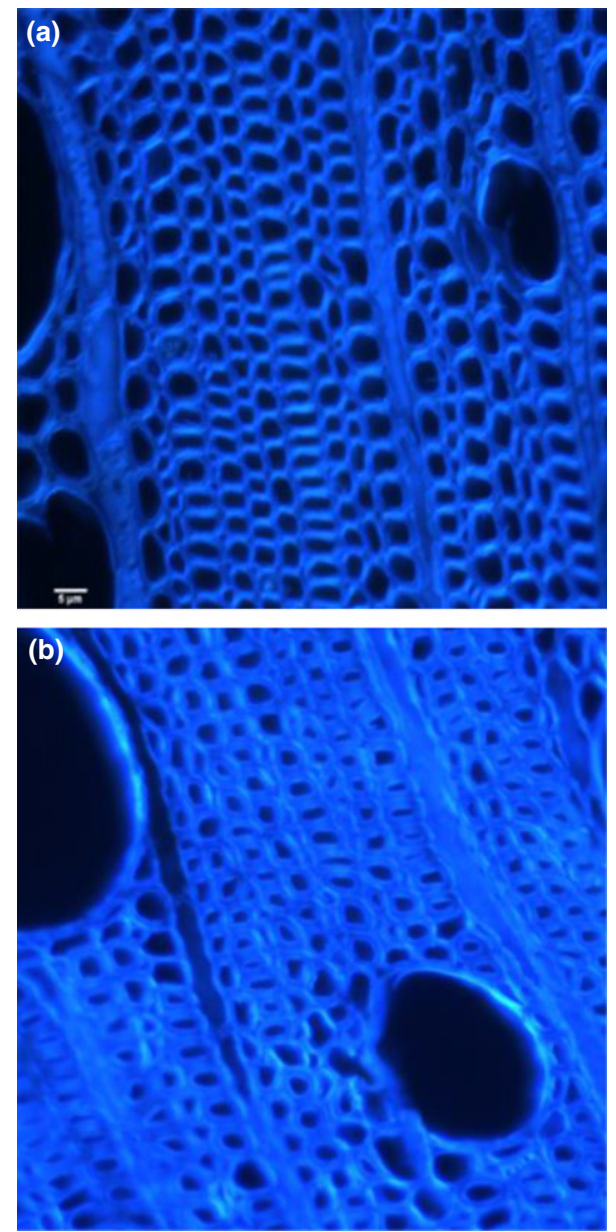

Fig. 1 Cell wall morphology of opposite wood (a) and tension wood (b) from an Eucalyptus grandis $\times$ Eucalyptus urophylla hybrid tree (ramet). Comparisons for all sampled ramets (Supporting Information Fig. S1) can be seen Fig. S2. Bar, $5 \mu \mathrm{m}$.

different between tension and opposite wood. In short, rhamnose and arabinose were not significantly different and showed the highest variation among trees, but xylose and mannose concentrations were significantly lower in tension wood. However, the largest difference in tension wood hemicellulose was in galactose content, which was c. 300\% higher in tension wood (mean 1.82 $\mathrm{mg} 100 \mathrm{mg}^{-1}$ DW compared with $0.58 \mathrm{mg} 100 \mathrm{mg}^{-1}$ in opposite wood). The insoluble lignin content was also significantly reduced in tension wood compared with opposite wood

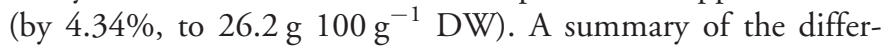
ences in all wood properties can be seen in Fig. 2 and Tables S2 and S3.

\section{Transcriptional response to induced tension wood formation}

To profile differential gene expression in tension wood-forming tissues, we collected xylem from three 18-month-old GUSAP1 trees that were bent for $3 \mathrm{wk}$. This experimental design permitted comparison with previous tension wood profiling experiments in Populus (Andersson-Gunnerås etal., 2006; Jin etal., 2011). However, the actual bending and sampling were performed in field-grown Eucalyptus trees, in this case, as opposed to potted glasshouse-grown poplar trees. Additional trees of the same age that had been bent in the same manner for 6 months in the field demonstrated observable tension wood at a macroscopic level (Fig. S3). RNA was extracted and RNA-seq (Illumina, San Diego, CA, USA) data produced from the xylem of three biological replicates of tension wood-forming trees (3 wk post-induction) and upright controls. Overall, we found 366 genes that were significantly $(q<0.05)$ differentially expressed in tension wood compared with the upright control sample (176 up-regulated and 190 down-regulated; Fig. S4, Tables S4, S5). Arabidopsis thaliana gene IDs homologous to the Eucalyptus gene IDs according to the E. grandis V.02 annotation (www.phytozome.net) were used for analysis using the BINGO (Maere et al., 2005) and GOToorBox (Martin et al., 2004) tools to identify overrepresentation of ontology terms in the differentially expressed genes (Figs S5, S6, Table S6).

In general, the most enriched biological processes in tension wood were genes related to the stress response (stress, chemical, abiotic and mechanical stimuli). In addition, and consistent with previous analyses of differentially regulated genes in tension

Table 2 Basic wood density, holocellulose, $\alpha$-cellulose and microfibril angle in tension and opposite wood of five ramets of Eucalyptus grandis $\times$ Eucalyptus urophylla $\mathrm{F}_{1}$ hybrid clone GUSAP1

\begin{tabular}{|c|c|c|c|c|}
\hline Sample & Wood density $\left(\mathrm{kg} \mathrm{m}^{-3}\right)$ & Holocellulose (mg 100 mg $^{-1}$ ) & $\alpha$-Cellulose (mg $100 \mathrm{mg}^{-1}$ ) & Microfibril angle $\left(^{\circ}\right)$ \\
\hline Opposite wood 1 & 460.28 & 64.35 & 38.29 & 21.23 \\
\hline Opposite wood 2 & 411.74 & 63.92 & 38.96 & 19.31 \\
\hline Opposite wood 3 & 504.38 & 65.28 & 37.29 & 18.42 \\
\hline Opposite wood 4 & 465.49 & 67.10 & 39.62 & 22.12 \\
\hline Opposite wood 5 & 531.19 & 65.24 & 40.47 & 18.55 \\
\hline Tension wood 1 & 483.04 & 64.34 & 41.86 & 15.23 \\
\hline Tension wood 2 & 413.49 & 62.81 & 39.66 & 16.25 \\
\hline Tension wood 3 & 516.17 & 66.68 & 41.93 & 14.33 \\
\hline Tension wood 4 & 507.82 & 71.61 & 42.04 & 14.59 \\
\hline Tension wood 5 & 483.78 & 69.97 & 40.14 & 15.48 \\
\hline Opposite wood (mean \pm SD) & $474.62 \pm 45.63$ & $65.18 \pm 1.22$ & $38.93 \pm 1.22$ & $19.92 \pm 0.74$ \\
\hline Tension wood (mean \pm SD) & $480.86 \pm 40.39$ & $67.08 \pm 3.70$ & $41.13 \pm 1.13 *$ & $15.18 \pm 0.34 * *$ \\
\hline
\end{tabular}

Paired, two-tailed $t$-test: * $P \leq 0.05 ; * *, P \leq 0.01$. 


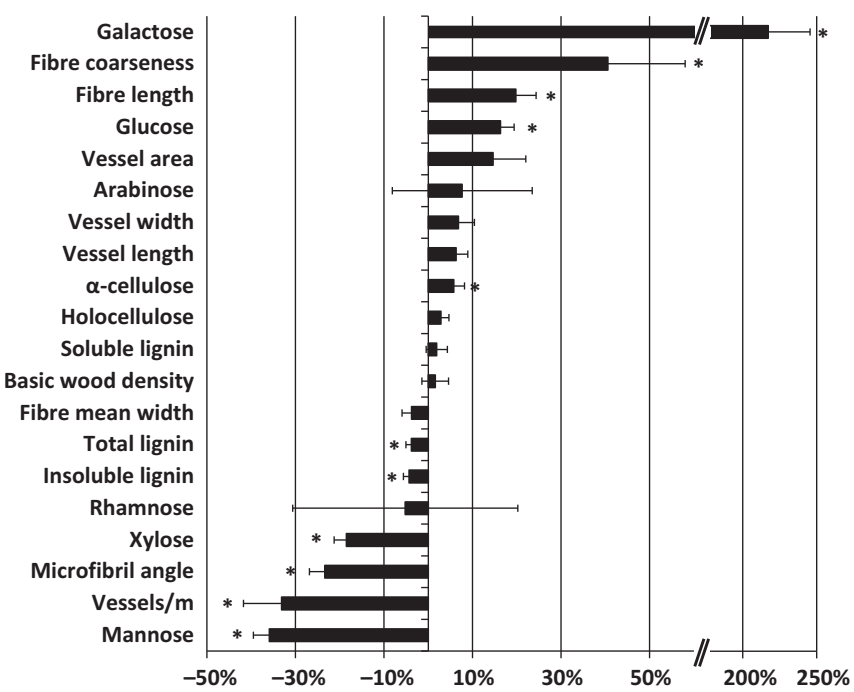

Fig. 2 Relative changes in wood properties between tension wood and opposite wood in five ramets of Eucalyptus grandis $\times$ Eucalyptus urophylla $\mathrm{F}_{1}$ hybrid clone GUSAP1. A positive change indicates a higher value in tension wood as compared with opposite wood, and a negative change indicates a lower value in tension wood compared with opposite wood. Error bars represent $\pm \mathrm{SE}(n=5)$. Paired, two-tailed $t$-test: ${ }^{*}, P \leq 0.05$.

wood, several genes coding for FASCICLIN-LIKE ARABINOGALACTAN (FLA) proteins were highly up-regulated FLA11 (Eucgr.B02486), FLA12 (Eucgr.J00938) and FLA17 (Eucgr.A02551) homologues. Other cell wall signalling-related genes were up-regulated, including two homologues of leucinerich repeat protein kinases (Eucgr.F02727 and Eucgr.L02854), annexin (Eucgr.F02423), IQ-Domain10 (IQD10; Eucgr.F01203) and a RAB GTPase homologue (Eucgr.B02741). Homologues of several transcription factors that have previously been associated with SCW biosynthesis were also up-regulated, including KNOTTED-LIKE HOMEOBOX OF ARABIDOPSIS THALIANA 7 (KNAT7) (Eucgr.D01935), MYB52 (Eucgr.F02756), a C3HC4-type RING finger zinc finger family protein (Eucgr.101697) and two C2H2-like zinc finger proteins (Eucgr.B02487 and Eucgr.H00574). The joint up-regulation of KNAT7 and MYB52 is interesting, as these genes have been shown to be co-regulated in $A$. thaliana and are both repressed by MYB7 (Ko et al., 2009), an orthologue of which (Eucgr.C00721) was down-regulated in the tension wood (Table S4). A homologue of MYB61 (Eucgr.B02197) was also up-regulated. In $A$. thaliana this gene has been shown to be expressed in sink tissues, and is essential for xylem formation (Romano et al., 2012). Other than general stress response-related ontologies, the only other categories enriched in the significantly up-regulated genes were 'positive regulation of cell death' (GO:0010942 and its child terms); 'disaccharide metabolism' (GO:0005984 and its child terms), relating to sucrose and trehalose metabolism; and 'methionine biosynthesis' (GO:0006555; Fig. S5, Table S6).

By contrast, enriched ontologies for down-regulated genes included phenylpropanoid and flavonoid biosynthesis, as well as the biosynthesis of phenylalanine, tyrosine and tryptophan (Fig. S6). Homologues of genes representing most of the 


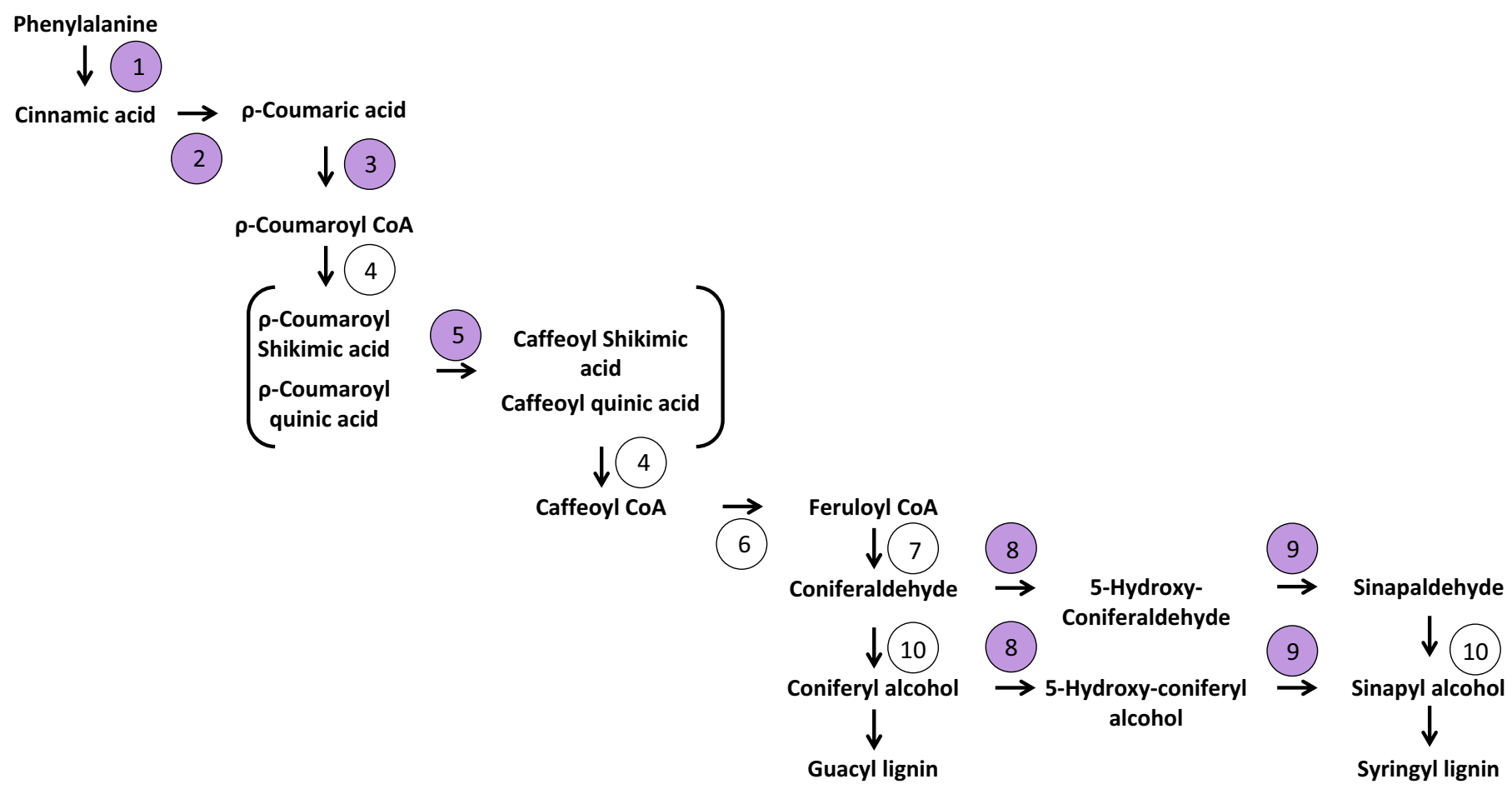

Fig. 3 Main steps of the monolignol biosynthetic pathway in Eucalyptus down-regulated in tension wood. Pathway construction is based on Humphreys \& Chapple (2002). Enzymatic steps where one or more representative genes showed significant down-regulation in tension wood xylem compared with the upright control in the Eucalyptus grandis $\times$ Eucalyptus urophylla hybrid clone are highlighted in purple. A full table of differential expression for all genes involved in the pathway (annotation according to V. Carocha et al., in preparation) is available in Supporting Information Table S7. Steps 1-10 represent the following reactions: 1 , phenylalanine ammonia-lyase (PAL); 2, cinnamate 4-hydroxylase (C4H); 3, 4-coumarate:CoA ligase (4CL);

4, p-hydroxycinnamoyl-CoA:quinate shikimate p-hydroxycinnamoyltransferase $(\mathrm{HCT}) ; 5$, 4-coumarate 3-hydroxylase $\left(\mathrm{C}^{\prime} \mathrm{H}\right)$; 6, caffeoyl-CoA O-methyltransferase (CCOAOMT); 7, cinnamoyl-CoA reductase (CCR); 8, ferulate 5-hydroxylase (F5H); 9, caffeic acid/5-hydroxyconiferaldehyde O-methyltransferase (COMT); 10, cinnamyl alcohol dehydrogenase (CAD).

enzymatic steps involved in the monolignol biosynthetic pathway were significantly down-regulated (Fig. 3), including $P A L$ (Eucgr.J00907), C4H (Eucgr.J01844), 4CL (Eucgr.K00087), C3'H (Eucgr.G03199), F5H (Eucgr.J02393) and COMT (Eucgr.A01397). Although evidence of large expansions has been noted for some of these gene families in E. grandis, 24 core 'bona fide lignifying' genes have been identified (V. Carocha et al., in preparation). With the exception of the CAD genes, most family members of all bona fide monolignol biosynthesis genes were down-regulated, although statistical significance was lacking for some (Table S7).

Given that significant increases in glucose, putatively stemming from increased $\alpha$-cellulose synthesis, were observed, as well as changes in the relative proportion of hemicellulosic components, we specifically examined the differential expression of genes involved in carbohydrate metabolism (Table 4). Among the up-regulated genes, a SUCROSE SYNTHASE 4 homologue (SUS4; Eucgr.CO3199), TRAHALOSE-PHOSPHATASE/ SYNTHASE 9 (Eucgr.B02686) and a gene coding for a trehalosephosphatase family protein (Eucgr.B02686) were significantly up-regulated, which could provide the increased source of UDPglucose needed to supply the cellulose synthase machinery. Additionally, a $\beta$-glucosidase GH1 coding gene (Eucgr.B00859) was up-regulated, which could be involved in cellulose modification in the cell wall. Although we saw no significant differences in expression of any of the cellulose synthase $(\operatorname{Ces} A)$ genes, we observed the expression of a tandem duplicate of EgCesA3 ( $E u$ cgr.C00246, orthologue of AtCesA7; Ranik \& Myburg, 2006) that has not been previously observed in Eucalyptus or annotated in the E. grandis genome. The tandem duplicate gene codes for an in-frame copy of Eucgr.C00246, and is expressed at a similar level (Fig. S7).

Several other genes encoding glycosyl transferases were also up-regulated, including GT32 ( $\alpha$-1,4-glycosyltransferase family protein; Eucgr.A00510) and GT35 (glycogen or starch phosphorylase; Eucgr.J01374). Another CAZyme gene transcriptionally up-regulated was GDP-D-mannose $3^{\prime}, 5^{\prime}$-epimerase $(G M E)$, known to be involved in ascorbate biosynthesis, pectic polysaccharide biosynthesis, and the general stress response (Wolucka \& Van Montagu, 2003; Caffall \& Mohnen, 2009; Smirnoff, 2011). Among the three identified possible enzymatic functions, the most commonly ascribed role (EC 5.1.3.18) is the catalytic conversion of GDP-D-mannose to GDP-L-galactose (Major et al., 2005). This is interesting, as tension wood displayed reduced mannose and increased galactose compared with opposite wood (Fig. 2). In general, with the exception of homologues of SUS4 and GLUCURONIC ACID SUBSTITUTION OF XYLAN 2 (GUX2; Eucgr.F00232), most of the CAZyme genes significantly 
Table 4 Carbohydrate active enzyme (CAZyme) genes significantly $(q<0.05)$ differentially expressed in 3-wk tension wood (TW) forming xylem of Eucalyptus grandis $\times$ Eucalyptus urophylla trees

\begin{tabular}{|c|c|c|c|c|c|c|}
\hline E. grandis ID & $\begin{array}{l}\text { Arabidopsis thaliana } \\
\text { homologue }\end{array}$ & Arabidopsis thaliana protein & $\begin{array}{l}\text { CAZyme } \\
\text { annotation* }\end{array}$ & $\begin{array}{l}\log _{\mathrm{e}} \text { (fold } \\
\text { change) }\end{array}$ & $\begin{array}{l}\text { Average FPKM } \\
\text { (upright) }^{\dagger}\end{array}$ & $\begin{array}{l}\text { Average } \\
\text { FPKM (TW) }\end{array}$ \\
\hline Eucgr.A00510 & AT2G38150 & $\alpha-1,4$-glycosyltransferase & GT32 & 4.24 & 0 & 43 \\
\hline Eucgr.H00343 & AT1G68470 & Exostosin family protein & GT47 & 3.87 & 2 & 143 \\
\hline Eucgr.I01697 & AT3G27330 & $\beta$-1,4-galactosyltransferase & GT92 & 3.71 & 3 & 153 \\
\hline Eucgr.B00354 & AT1G23870 & ATTPS9, TPS9 & GT20 & 3.00 & 1 & 13 \\
\hline Eucgr.I01147 & AT1G49710 & FUCTB, FUT12 & GT10 & 2.25 & 14 & 111 \\
\hline Eucgr.K00865 & AT4G15240 & Unknown (DUF604) & GT31 & 1.78 & 9 & 71 \\
\hline Eucgr.B00859 & AT3G18080 & BGLU44 & $\mathrm{GH} 1$ & 1.51 & 10 & 26 \\
\hline Eucgr.B02686 & AT1G68020.2 & ATTPS6, TPS6 & GT20 & 1.49 & 9 & 36 \\
\hline Eucgr.F03658 & AT1G55740 & AtSIP1, SIP1 & $\mathrm{GH} 36$ & 1.48 & 10 & 41 \\
\hline Eucgr.E01169 & AT4G19420 & PAE8 & CE13 & 1.36 & 40 & 121 \\
\hline Eucgr.F01855 & AT1G45130 & BGAL5 & GH35 & 1.19 & 5 & 14 \\
\hline Eucgr.J01374 & AT3G29320 & $\alpha$-Glucan phosphorylase & GT35 & 1.12 & 5 & 14 \\
\hline Eucgr.B02118 & AT5G28840 & GME & & 1.12 & 13 & 38 \\
\hline Eucgr.F00232 & AT4G33330 & GUX2, PGSIP3 & GT8 & 0.94 & 101 & 386 \\
\hline Eucgr.H00536 & AT3G17880 & HIP, TDX & GT41 & 0.90 & 20 & 43 \\
\hline Eucgr.C03199 & АT3G43190 & SUS4 & GT4 & 0.49 & 1144 & 1614 \\
\hline Eucgr.J02867 & AT3G13750 & BGAL1 & GH35 & -0.84 & 28 & 10 \\
\hline Eucgr.G02748 & AT5G04310 & Pectin lyase-like & PL1 & -1.00 & 29 & 12 \\
\hline Eucgr.G02887 & AT5G04310 & Pectin lyase-like & PL1 & -1.12 & 11 & 1 \\
\hline Eucgr.F02205 & AT1G58370 & ATXYN1, RXF12 & $\mathrm{CBM} 22$ & -1.26 & 16 & 5 \\
\hline Eucgr.K03600 & AT4G13710 & Pectin lyase-like & PL1 & -1.26 & 22 & 8 \\
\hline Eucgr.A00780 & AT5G01930 & MAN6 & $\mathrm{GH} 5$ & -1.37 & 72 & 20 \\
\hline Eucgr.A00485 & AT1G19300 & GATL1, PARVUS & GT8 & -1.51 & 196 & 46 \\
\hline Eucgr.C03207 & АT3G43190 & ATSUS4, SUS4 & GT4 & -2.74 & 10 & 1 \\
\hline
\end{tabular}

*Annotation of CAZymes according to Yin et al. (2012). ${ }^{\dagger}$ Average fragments per kilobase of coding sequence per million mapped fragments (FPKM) of three biological replicates.

up-regulated in tension wood showed very low or no expression in the upright control (Table 4), and there is no indication of transcriptional rewiring of CAZymes' roles normally associated with SCW polysaccharide metabolism, as previously demonstrated in Populus (Andersson-Gunnerås et al., 2006). The downregulation of PARVUS (Eucgr.A00485) is notable, as it could be responsible for the reduction in xylose content observed in tension wood.

Several genes associated with changes in hormone metabolism were also differentially expressed during tension wood formation
(Table 5). In short, genes associated with elevated activity in the synthesis of ethylene, GA and jasmonic acid in tension wood relative to the upright control was apparent. One of the most highly up-regulated genes in tension wood (50-fold up-regulation) was a homologue of ACC OXIDASE 4lETHYLENE FORMING ENZYME (ACO4lEFE; Eucgr.D01368), which is involved in the final step in ethylene formation from methionine by converting 1-aminocyclopropane-1-carboxylate to ethylene. Interestingly, this was contrasted by an almost complete suppression of an ACO1 homologue expressed in the upright control

Table 5 Hormone-related genes significantly differentially $(q<0.05)$ expressed in 3-wk tension wood forming xylem of Eucalyptus grandis $\times$ Eucalyptus urophylla trees

\begin{tabular}{|c|c|c|c|c|c|c|}
\hline E. grandis ID & $\begin{array}{l}\text { Arabidopsis thaliana } \\
\text { homologue }\end{array}$ & Arabidopsis thaliana protein & $\begin{array}{l}\log _{e}(\text { fold } \\
\text { change) }\end{array}$ & $\begin{array}{l}\text { Average FPKM* } \\
\text { (upright) }\end{array}$ & $\begin{array}{l}\text { Average } \\
\text { FPKM* (TW) }^{*}{ }^{*} \text { (TW }\end{array}$ & Hormonal pathway \\
\hline Eucgr.B03366 & AT5G14920 & - & 4.05 & 2 & 124 & Gibberellic acid \\
\hline Eucgr.D01368 & AT1G05010 & $\mathrm{EFE}, \mathrm{ACO} 4$ & 3.68 & 15 & 807 & Ethylene \\
\hline Eucgr.E03916 & AT5G47530 & - & 2.83 & 5 & 110 & Auxin \\
\hline Eucgr.H04545 & AT1G56220 & - & 1.62 & 30 & 220 & Auxin \\
\hline Eucgr.H03965 & AT3G16770 & RAP2.3, ATEBP, ERF72, EBP & 1.33 & 12 & 69 & Ethylene \\
\hline Eucgr.C03183 & AT4G33150 & LKR, ISDH & 1.21 & 7 & 17 & Jasmonic acid \\
\hline Eucgr.H03171 & AT1G04240 & SHY2, IAA3 & -1.11 & 20 & 7 & Auxin \\
\hline Eucgr.H02914 & AT2G33310 & IAA13 & -1.34 & 25 & 10 & Auxin \\
\hline Eucgr.G01769 & AT2G21050 & LAX2 & -1.50 & 121 & 39 & Auxin \\
\hline Eucgr.C03886 & AT2G19590 & ACO1 & -3.09 & 87 & 4 & Ethylene \\
\hline Eucgr.C02930 & AT4G32810 & CCD8,MAX4 & -6.05 & 23 & 0 & Auxin \\
\hline
\end{tabular}

*Average per kilobase of coding sequence per million mapped fragments (FPKM) in three biological replicates. 
(Eucgr.C03886; Table 5), suggesting that a different family member is recruited for ethylene synthesis in Eucalyptus tension wood compared with normal wood. The enzymatic function of ACC OXIDASE has previously been highlighted in tension woodforming tissues of Populus, in producing ethylene to stimulate asymmetrical cambial growth (Andersson-Gunnerås et al., 2003; Love etal., 2009). Of note was the up-regulation of an ethylene response transcription factor, Eucgr.F03499, a homologue of $A$. thaliana ETHELENE RESPONSE FACTOR 72 (ERF72). In Populus hybrids, the overexpression of ERF72 orthologues (named PtiERF34 and PtiERF35) caused significant increases in the diameter (either gene) and height (PtiERF35 only) of transgenic trees (Vahala et al., 2013). Similarly, in GA signalling, a homologue of an $A$. thaliana gibberellin-response protein, Eucgr.B03366, was highly up-regulated. The largest group of genes related to hormonal response was auxin-response genes, which showed both significant up- and down-regulation. Among these was the down-regulation of an oxireductase (CAROTENOID CLEAVAGE DIOXYGENASE 8 (CCD8); Eucgr.C02930) associated with polar auxin transport and the suppression of branching (Auldridge et al., 2006). Given that auxin, GA and ethylene are expected to be globally increased in xylogenic tissue of tension wood, these results are consistent with previous reports of hormonal changes in tension wood formation in Populus, suggesting a conserved mechanism between species.

\section{Discussion}

Tension wood represents an important developmental state consisting of both altered transcriptional and hormonal regulation, and the coordination of cellular processes recruited to alter cell wall chemical constituents. Although several studies have looked at aspects of tension wood in Eucalyptus, most of the information - especially regarding gene expression and biological changes has been based on studies in Populus. It was thus not known if the physiological processes in Eucalyptus would be similar to those observed in Populus, as no study has as yet looked at the detailed physiology of tension wood formation, or indeed profiled gene expression at whole-transcriptome level during tension wood formation in this genus. In this study, we report the first data investigating transcriptome-wide changes manifested during tension wood formation in field-grown Eucalyptus trees, and comprehensively describe the physicochemical changes that accompany this developmental response to mechanical stress in woody stems.

Despite the high variation in transcript abundance, which is expected in experiments on field-grown plants, trends in gene expression supported many of the observed physicochemical changes. The number of significantly differentially expressed genes (366) is similar to the 444 previously reported in a controlled, glasshouse-grown Populus study at a similar time-point post induction (Andersson-Gunnerås et al., 2006). It is noteworthy that, among the most significantly differentially expressed genes, several common observations could be made between Eucalyptus and Populus (Table S8) in terms of up-regulation of ethylene biosynthesis (EFE/ACO4) and response (ERF72), UDP- glucose production (SUSY), transcriptional regulators (KNAT7, MYB52 and At3g27330 homologs) and cell wall signalling genes (FLA12), the reduction in the expression of PARVUS which is associated with xylan synthesis, and the down-regulation of most lignin-related genes. This suggests common mechanisms employed by these two woody dicots in regulating and forming tension wood.

In general, the data for morphological and chemical changes concur with those previously obtained in tension wood of various angiosperm species, namely longer fibres, a higher fibre:vessel ratio, relatively increased cellulose with a decreased (smaller relative to the long axis of the fibre) MFA, and a relative decrease in lignin (Tables 1-3). In terms of hemicellulose biosynthesis, we found that, in Eucalyptus tension wood, xylan is significantly reduced, and this may be a consequence of the 4-fold down-regulation of the PARVUS gene (Table 4). The simultaneous strong up-regulation of a homologue of GUX2 (Eucgr.F00232) in tension wood should also be noted, as $G U X$ genes are responsible for glucuronic acid (GlcA) side-chain addition onto the xylan backbone (Mortimer et al., 2010; Lee et al., 2012). It would be interesting to further characterize tension wood xylan to see whether the side-chain structure is modified and what effect that may have on the structural properties of the SCW (e.g. increasing wood flexibility and tolerance to mechanical perturbations). The relative reduction of xylan in tension wood and the increase in $\alpha$ cellulose are consistent with the generally accepted model of physicochemical changes in tension wood, but do not agree with previous tension wood physicochemical characterizations of E. globulus that showed an increase in xylan and no change in cellulose (Aguayo et al., 2010, 2012), although a reduction in lignin is consistently found.

Evidence for the increase in fibre cell formation in tension wood can be seen in the increase in the proportion of fibres (Table 1), which at a molecular level is evident in the up-regulation of methionine metabolism for ethylene production and GA and auxin signalling, as well as increased ontologies associated with programmed cell death (Tables 5, S6, Fig. S5). In terms of compositional changes in fibre SCW, the CAZymes observed to be up-regulated in tension wood-forming tissue (with the exception of GT8 and GT4) have been observed to be generally ubiquitously expressed across multiple tissues/organs of E. grandis or specific to primary cell wall tissues (Tables 4, S9). This observation could be attributable to the fact that tension wood produces increased amounts of carbohydrates generally not found in high abundance in Eucalyptus SCWs (such as galactose; Table 3, Fig. 2).

It is unclear in what form galacatose is present in the cell wall, as it could make up components of FLAs (Seifert \& Roberts, 2007) or pectic compounds such as the side chains of rhamnogalacturonan I (Goubet et al., 1995; Scheller et al., 2007), or indeed be present as pure galactan. Nevertheless, the role of galactose and galactan in SCW and G-layer deposition, especially pertaining to orientation of cellulose microfibrils during cellulose deposition, has been previously highlighted (Gorshkova \& Morvan, 2006; Roach et al., 2011). Several studies have also reported the presence of $\beta-(1 \rightarrow 4)$ galactan and an increase in $\beta-(1 \rightarrow 6)$ 
galactan in tension wood, some of unique composition not usually found in upright wood (Meier, 1962). We identified a homologue of the gene AT3G27330, encoding a protein of unknown function that has been annotated as possessing a GT92 domain (Yin et al., 2012), also present in all three recently characterized GALACTAN SYNTHASE 1, 2 and 3 proteins, which were sufficient to increase cell wall galactan content (Liwanag et al., 2012). This gene is not normally expressed in Eucalyptus xylem (Table S5), but is up-regulated in tension wood (Table 4), and would be a candidate for tension wood-specific $\beta$ - $(1 \rightarrow 4)$ galactan synthesis.

The relative changes in cellulose quantity and properties are more complex, but are probably related to an increased carbon flux to UDP-glucose via SUSY, and/or a possible post-transcriptional/post-translational mechanism(s) that was not apparent in this study. The reduction in lignin can be attributed to a significant reduction in the expression of the suite of monolignol biosynthetic genes (Fig. 3, Table S7), as well as those involved in shikimate biosynthesis (Eucgr.H01214) and phenylalanine metabolism (Eucgr.J00428; Table S5). Together with enriched ontologies represented by up-regulated genes, it is our conclusion that, at a transcriptional level, the underlying molecular mechanism controlling Eucalyptus tension wood physiology is probably a reduction in lignin monomer production and xylan biosynthesis, and synthesis of polysaccharides not usually occurring in wood, rather than the relative up-regulation of pathways involved in secondary cell wall cellulose synthesis, as previously described.

Taken together, the findings of differentially expressed CAZymes provide new insight into changes in fibre cell wall size and composition in Eucalyptus tension wood. Recently, the function of PECTIN ACETYL ESTERASE 8 (PAE8, E. grandis homologue Eucgr.E01169) has been identified as deacetylating RG I in $A$. thaliana (de Souza et al., 2014). Based on the differential GT and GH expression, and the wall changes in mannose and galactose, it is conceivable that during tension wood formation glucomannan is reduced by the shunting of mannose towards galactose production via GME. Galactose is incorporated into $\beta$ - $(1 \rightarrow 4)$ galactan (both GT92- and GT32-containing genes up-regulated in Eucalyptus would be candidates for this; Table 4), and is probably incorporated into the wall as RG I in conjunction with FLA12. A modification of acetylation of RG I by PAE8 could theoretically decrease hydrophobicity and increase access to enzymatic breakdown (Busse-Wicher et al., 2014; de Souza et al., 2014 ) by, for example, $\beta$-galactosidases for cell wall remodelling (Roach et al., 2011). Further reduction of glucomannan in the wall would occur via reduction of glucomannan synthase (although not detected as significant, the transcript level of the E. grandis homologue of CELLULOSE SYNTHASE LIKE A 9 (CSLA9), Eucgr.A01558, was reduced by $c$. 4-fold in tension wood across all biological replicates; Table S5). Finally, although this should be tested in Eucalyptus in the future, the relative increase in cell wall deposition could be partially attributed to down-regulation of MAN6 (Eucgr.A00780; Table 4). Suppression of the extracellular endo-1,4- $\beta$-mannanase MAN6 has been shown to increase SCW deposition in Populus by reducing mannose oligosaccharide signalling from the wall (Zhao et al., 2013).
An aspect that still is not fully resolved, however, is the composition and interactions of matrix polysaccharides and the mechanism of tension generation. For example, the role of xyloglucan has been previously highlighted as playing a key role in generation of tension stress, with Xyloglucan endotransglucosylase/hydrolase (XET/XTH) enzymes providing the necessary active remodelling of interactions with crystalline cellulose (reviewed in Mellerowicz et al., 2008; Mellerowicz \& Gorshkova, 2012). Contrary to several previous tension wood studies, we observed no significant differential expression for any of the c. 40 annotated XET/XTH E. grandis homologues at $3 \mathrm{wk}$ post induction in field-grown trees. Data generated in this study are more supportive of the paradigm where a change in the cellulose microfibril angle combined with a more hygroscopic cell wall composition would generate the tension necessary to oppose mechanical stress. In this paradigm, there is a decrease in MFA and shortening of the fibres in the case of angiosperms to generate tension at the top (Burgert \& Fratzl, 2009), or an increase in MFA to lengthen fibres in compression wood at the bottom as observed in coniferous gymnosperms (Burgert etal., 2007). This de-emphasizes specific architecture of the matrix polysaccharides but places greater emphasis on the orientation of cellulose fibrils, the chemical composition of the matrix and the resulting deformation allowable by relative matrix shear. Although it should not be discounted (fibre/tracheid cell length is still a critical factor of all types of reaction wood and XTHs play an important role in influencing primary elongation of fibres), the proposed role of XTHs in generating tension remains to be proven. Nevertheless, up-regulation of XTH genes has been demonstrated before in Eucalyptus during early tension wood formation (Paux et al., 2005; Goulao etal., 2011). The relative importance of active generation of tension by remodelling via hydolases (xyloglucan or galactose), as opposed to shrinking by matrix deformation, is still not resolved, and could be related to the type or developmental stage of tension wood formation.

Part of the novelty of this study is the fact that both physicochemical analyses and gene expression analyses were performed in field-grown trees. On the one hand, this introduces large biological variation and noise attributable to other environmental stressors such as interaction with pests and pathogens, and variability in light and temperature conditions that would not be found under laboratory conditions. Perhaps of most relevance to this study, these clonal stands are subject to constant coastal winds and especially young upright trees are constantly reacting to mechanical stress. This would create either microscopic regions of tension wood along the stem or, if evenly spread out, contribute to the overall low MFA and high crystallinity of cellulose observed in eucalypts. On the other hand, despite this variation, responses involving reduction of lignin, xylan and mannan, both in the wood chemistry and the molecular responses observed, were comparable with previous laboratory studies of tension wood formation. The results observed herein could be argued to be the most realistic biological response to mechanical stress in the field, over and above the normal wind and gravitational stresses experienced by a growing tree. 
Eucalyptus is a commercially important hardwood genus, and the forest products industry will in the future undoubtedly rely on more sophisticated biotechnology strategies to enhance woody biomass traits. These strategies depend on understanding the roles of genes and biological processes during xylogenesis, including those involved in hormonal changes, cellular patterning, carbohydrate composition and cell wall ultrastructure. In this study, we have shown that gene expression and wood property changes during tension wood formation in field-grown Eucalyptus trees are to an extent consistent with previous results from model systems, highlighting key pathways and genes putatively involved in Eucalyptus tension wood formation specifically. Detailed microstructural studies will be needed to resolve any novel tension wood-specific polysaccharides or glycoprotein modifications, but this study suggests that the deposition of galactans not normally associated with secondary cell walls may play a role in tension wood formation or function in Eucalyptus. In the future, strategies to modify wood cell wall composition or ultrastructure in eucalypts will probably involve attenuation or overexpression of key genes, but could also involve the integration of novel biopolymers not normally found in wood.

\section{Acknowledgements}

The authors would like to acknowledge M. Ranik and M. O'Neill (University of Pretoria) for the mRNA-seq library preparations and the sequencing facility at Oregon State University for assistance with RNA sequencing. Plant material was kindly provided by Sappi Forest Research (KwaMbonambi, South Africa). This work was supported through a strategic research grant from the South African Department of Science and Technology (DST) and by research funding from Sappi and Mondi, through the Forest Molecular Genetics Programme, the Technology and Human Resources for Industry Programme (THRIP, UID 80118) and the Bioinformatics and Functional Genomics Programme of the National Research Foundation (NRF, UID 18312) of South Africa.

\section{References}

Abràmoff MD, Magalhães PJ, Ram SJ. 2004. Image processing with ImageJ. Biophotonics International 11: 36-42.

Aguayo MG, Mendonça RT, Martínez P, Rodríguez J, Pereira M. 2012. Chemical characteristics and Kraft pulping of tension wood from Eucalyptus globulus Labill. Revista Árvore 36: 1163-1172.

Aguayo MG, Quintupill L, Castillo R, Baeza J, Freer J, Mendonça RT. 2010. Determination of differences in anatomical and chemical characteristics of tension and opposite wood of 8-year old Eucalyptus globulus. Maderas: Ciencia y Tecnologia 12: 241-251.

Al-Haddad JM, Kang K-Y, Mansfield SD, Telewski FW. 2013. Chemical responses to modified lignin composition in tension wood of hybrid poplar (Populus tremula $\times$ Populus alba). Tree Physiology 33: 365-373.

Andersson-Gunnerås S, Hellgren JM, Björklund S, Regan S, Moritz T, Sundberg B. 2003. Asymmetric expression of a poplar ACC oxidase controls ethylene production during gravitational induction of tension wood. Plant Journal 34: 339-349.

Andersson-Gunnerås S, Mellerowicz EJ, Love J, Segerman B, Ohmiya Y, Coutinho PM, Nilsson P, Henrissat B, Moritz T, Sundberg B. 2006.
Biosynthesis of cellulose-enriched tension wood in Populus: global analysis of transcripts and metabolites identifies biochemical and developmental regulators in secondary wall biosynthesis. Plant Journal 45: 144-165.

Aoyama W, Matsumura A, Tsutsumi Y, Nishida T. 2001. Lignification and peroxidase in tension wood of Eucalyptus viminalis seedlings. Journal of Wood Science 47: 419-424.

Auldridge ME, Block A, Vogel JT, Dabney-Smith C, Mila I, Bouzayen M, Magallanes-Lundback M, DellaPenna D, McCarty DR, Klee HJ. 2006. Characterization of three members of the Arabidopsis carotenoid cleavage dioxygenase family demonstrates the divergent roles of this multifunctional enzyme family. Plant Journal 45: 982-993.

Baba K, Karlberg A, Schmidt J, Schrader J, Hvidsten TR, Bako L, Bhalerao RP. 2011. Activity-dormancy transition in the cambial meristem involves stagespecific modulation of auxin response in hybrid aspen. Proceedings of the National Academy of Sciences, USA 108: 3418-3423.

Baba K, Park YW, Kaku T, Kaida R, Takeuchi M, Yoshida M, Hosoo Y, Ojio Y, Okuyama T, Taniguchi T et al. 2009. Xyloglucan for generating tensile stress to bend tree stem. Molecular Plant 2: 893-903.

Bentum ALK, Côté WA Jr, Day AC, Timell TE. 1969. Distribution of lignin in normal and tension wood. Wood Science and Technology 3: 218-231.

Björklund S, Antti H, Uddestrand I, Moritz T, Sundberg B. 2007. Cross-talk between gibberellin and auxin in development of Populus wood: gibberellin stimulates polar auxin transport and has a common transcriptome with auxin. Plant Journal 52: 499-511.

Bowling AJ, Vaughn KC. 2008. Immunocytochemical characterization of tension wood: gelatinous fibers contain more than just cellulose. American Journal of Botany 95: 655-663.

Browning B. 1967. Methods of wood chemistry. New York, NY, USA: Wiley Interscience.

Burgert I, Eder M, Gierlinger N, Fratzl P. 2007. Tensile and compressive stresses in tracheids are induced by swelling based on geometrical constraints of the wood cell. Planta 226: 981-987.

Burgert I, Fratzl P. 2009. Plants control the properties and actuation of their organs through the orientation of cellulose fibrils in their cell walls. Integrative and Comparative Biology 49: 69-79.

Busse-Wicher M, Gomes TC, Tryfona T, Nikolovski N, Stott K, Grantham NJ, Bolam DN, Skaf MS, Dupree P. 2014. The pattern of xylan acetylation suggests xylan may interact with cellulose microfibrils as a two-fold helical screw in the secondary plant cell wall of Arabidopsis thaliana. Plant Journal 79: 492-506.

Caffall KH, Mohnen D. 2009. The structure, function, and biosynthesis of plant cell wall pectic polysaccharides. Carbohydrate Research 344: 1879-1900.

Chang S, Puryear J, Cairney J. 1993. A simple and efficient method for isolating RNA from pine trees. Plant Molecular Biology Reporter 11: 113-116.

Clair B, Alméras T, Pilate G, Jullien D, Sugiyama J, Riekel C. 2011. Maturation stress generation in poplar tension wood studied by synchrotron radiation microdiffraction. Plant Physiology 155: 562-570.

Clair B, Alméras T, Yamamoto H, Okuyama T, Sugiyama J. 2006a. Mechanical behavior of cellulose microfibrils in tension wood, in relation with maturation stress generation. Biophysical Journal 91 : 1128-1135.

Clair B, Ruelle J, Beauchêne J, Prévost MF, Fournier M. 2006b. Tension wood and opposite wood in 21 tropical rain forest species. 1. Occurrence and efficiency of the G-layer.. IAWA Journal 27: 329-338.

Coleman HD, Yan J, Mansfield SD. 2009. Sucrose synthase affects carbon partitioning to increase cellulose production and altered cell wall ultrastructure. Proceedings of the National Academy of Sciences, USA 106: 13118-13123.

Côté WA Jr, Day AC, Timell TE. 1969. A contribution to the ultrastructure of tension wood fibers. Wood Science and Technology 3: 257-271.

Elo A, Immanen J, Nieminen K, Helariutta Y. 2009. Stem cell function during plant vascular development. Seminars in Cell and Developmental Biology 20: 1097-1106.

Falconer MM, Seagull RW. 1985. Immunofluorescent and calcofluor white staining of developing tracheary elements in Zinnia elegans L. suspension cultures. Protoplasma 125: 190-198.

Fang CH, Clair B, Gril J, Alméras T. 2007. Transverse shrinkage in G-fibers as a function of cell wall layering and growth strain. Wood Science and Technology 41: 659-671 
Fang CH, Clair B, Gril J, Liu SQ. 2008. Growth stresses are highly controlled by the amount of G-layer in poplar tension wood. Iawa Journal 29: 237-246.

Gorshkova T, Morvan C. 2006. Secondary cell-wall assembly in flax phloem fibres: role of galactans. Planta 223: 149-158.

Goswami L, Dunlop JWC, Jungnikl K, Eder M, Gierlinger N, Coutand C, Jeronimidis G, Fratzl P, Burgert I. 2008. Stress generation in the tension wood of poplar is based on the lateral swelling power of the G-layer. Plant Journal 56: 531-538.

Goubet F, Bourlard T, Girault R, Alexandre C, Vandevelde MC, Morvan C. 1995. Structural features of galactans from flax fibres. Carbohydrate Polymers 27: $221-227$

Goulao LF, Vieira-Silva S, Jackson PA. 2011. Association of hemicellulose- and pectin-modifying gene expression with Eucalyptus globulus secondary growth. Plant Physiology and Biochemistry 49: 873-881.

Humphreys JM, Chapple C. 2002. Rewriting the lignin roadmap. Current Opinion in Plant Biology 5: 224-229.

Jin H, Do J, Moon D, Noh EW, Kim W, Kwon M. 2011. EST analysis of functional genes associated with cell wall biosynthesis and modification in the secondary xylem of the yellow poplar (Liriodendron tulipifera) stem during early stage of tension wood formation. Planta 234: 959-977.

Joseleau JP, Imai T, Kuroda K, Ruel K. 2004. Detection in situ and characterization of lignin in the G-layer of tension wood fibres of Populus deltoides. Planta 219: 338-345.

Jourez B, Riboux A, Leclercq A. 2001. Anatomical characteristics of tension wood and opposite wood in young inclined stems of poplar (Populus euramericana cv 'Ghoy'). IAWA Journal 22: 133-157.

Ko JH, Han KH, Park S, Yang J. 2004. Plant body weight-induced secondary growth in Arabidopsis and its transcription phenotype revealed by wholetranscriptome profiling. Plant Physiology 135: 1069-1083.

Ko JH, Kim WC, Han KH. 2009. Ectopic expression of MYB46 identifies transcriptional regulatory genes involved in secondary wall biosynthesis in Arabidopsis. Plant Journal 60: 649-665.

Lafarguette F, Leplé JC, Déjardin A, Laurans F, Costa G, Lesage-Descauses MC, Pilate G. 2004. Poplar genes encoding fasciclin-like arabinogalactan proteins are highly expressed in tension wood. New Phytologist 164: 107121.

Lee C, Teng Q, Zhong R, Ye ZH. 2012. Arabidopsis GUX proteins are glucuronyltransferases responsible for the addition of glucuronic acid side chains onto xylan. Plant and Cell Physiology 53: 1204-1216.

Leinonen R, Sugawara H, Shumway M. 2010. The sequence read archive. Nucleic Acids Research 39: D19-D21.

Little CHA, Savidge RA. 1987. 7. The role of plant growth regulators in forest tree cambial growth. Plant Growth Regulation 6: 137-169.

Liwanag AJM, Ebert B, Verhertbruggen Y, Rennie EA, Rautengarten C, Oikawa A, Andersen MC, Clausen MH, Scheller HV. 2012. Pectin biosynthesis: GALS1 in Arabidopsis thaliana is a $\beta-1,4$-galactan $\beta-1,4-$ galactosyltransferase. The Plant Cell Online 24: 5024-5036.

Lloyd C. 2011. Dynamic microtubules and the texture of plant cell walls. International Review of Cell and Molecular Biology 287: 287-329.

Love J, Björklund S, Vahala J, Hertzberg M, Kangasjärvi J, Sundberg B. 2009. Ethylene is an endogenous stimulator of cell division in the cambial meristem of Populus. Proceedings of the National Academy of Sciences, USA 106: 5984 5989.

Maere S, Heymans K, Kuiper M. 2005. BiNGO: a Cytoscape plugin to assess overrepresentation of Gene Ontology categories in biological networks. Bioinformatics 21: 3448-3449.

Major LL, Wolucka BA, Naismith JH. 2005. Structure and function of GDPmannose- $3^{\prime}, 5^{\prime}$-epimerase: an enzyme which performs three chemical reactions at the same active site. Journal of the American Chemical Society 127: 1830918320.

Martin D, Brun C, Remy E, Mouren P, Thieffry D, Jacq B. 2004. GOToolBox: functional analysis of gene datasets based on Gene Ontology. Genome Biology 5: R101.

Meier H. 1962. Studies on a galactan from tension wood of beech (Fagus silvatica L.). Acta Chemica Scandinavica 16: 14.
Mellerowicz EJ, Gorshkova TA. 2012. Tensional stress generation in gelatinous fibres: a review and possible mechanism based on cell-wall structure and composition. Journal of Experimental Botany 63: 551-565.

Mellerowicz EJ, Immerzeel P, Hayashi T. 2008. Xyloglucan: the molecular muscle of trees. Annals of Botany 102: 659-665.

Mortimer JC, Miles GP, Brown DM, Zhang Z, Segura MP, Weimar T, Yu X, Seffen KA, Stephens E, Turner SR et al. 2010. Absence of branches from xylan in Arabidopsis gux mutants reveals potential for simplification of lignocellulosic biomass. Proceedings of the National Academy of Sciences, USA 107: 1740917414.

Moyle R, Schrader J, Stenberg A, Olsson O, Saxena S, Sandberg G, Bhalerao RP. 2002. Environmental and auxin regulation of wood formation involves members of the Aux/IAA gene family in hybrid aspen. Plant Journal 31: 675685.

Muller M, Burghammer M, Sugiyama J. 2006. Direct investigation of the structural properties of tension wood cellulose microfibrils using microbeam Xray fibre diffraction. Holzforschung 60: 474-479.

Myburg AA, Grattapaglia D, Tuskan GA, Hellsten U, Hayes RD, Grimwood J, Jenkins J, Lindquist E, Tice H, Bauer D et al. 2014. The genome of Eucalyptus grandis. Nature 510: 356-362.

Nishikubo N, Awano T, Banasiak A, Bourquin V, Ibatullin F, Funada R, Brumer H, Teeri TT, Hayashi T, Sundberg B et al. 2007. Xyloglucan endotransglycosylase (XET) functions in gelatinous layers of tension wood fibers in poplar - a glimpse into the mechanism of the balancing act of trees. Plant and Cell Physiology 48: 843-855.

Okuyama T, Yamamoto H, Yoshida M, Hattori Y, Archer RR. 1994. Growth stresses in tension wood: role of microfibrils and lignification. Annales des Sciences Forestieres 51: 291-300.

Paux E, Carocha V, Marques C, De Sousa AM, Borralho N, Sivadon P, GrimaPettenati J. 2005. Transcript profiling of Eucalyptus xylem genes during tension wood formation. New Phytologist 167: 89-100.

Pesquet E, Tuominen H. 2011. Ethylene stimulates tracheary element differentiation in Zinnia elegans cell cultures. New Phytologist 190: 138-149.

Qiu D, Wilson IW, Gan S, Washusen R, Moran GF, Southerton SG. 2008. Gene expression in Eucalyptus branch wood with marked variation in cellulose microfibril orientation and lacking G-layers. New Phytologist 179: 94-103.

Ranik M, Myburg AA. 2006. Six new cellulose synthase genes from Eucalyptus are associated with primary and secondary cell wall biosynthesis. Tree Physiology 26: 545-556.

Roach MJ, Mokshina NY, Badhan A, Snegireva AV, Hobson N, Deyholos MK, Gorshkova TA. 2011. Development of cellulosic secondary walls in flax fibers requires $\beta$-galactosidase. Plant Physiology 156: 1351-1363.

Romano JM, Dubos C, Prouse MB, Wilkins O, Hong H, Poole M, Kang KY, Li E, Douglas CJ, Western TL. 2012. AtMYB61, an R2R3-MYB transcription factor, functions as a pleiotropic regulator via a small gene network. New Phytologist 195: 774-786.

Ruelle J, Beauchêne J, Yamamoto H, Thibaut B. 2010. Variations in physical and mechanical properties between tension and opposite wood from three tropical rainforest species. Wood Science and Technology 45: 339-537.

Ruelle J, Clair B, Beauchene J, Prévost MF, Fournier M. 2006. Tension wood and opposite wood in 21 tropical rain forest species 2. Comparison of some anatomical and ultrastructural criteria. IAWA Journal 27: 341-376.

Scheller HV, Jensen JK, Sørensen SO, Harholt J, Geshi N. 2007. Biosynthesis of pectin. Physiologia Plantarum 129: 283-295.

Schroeder A, Mueller O, Stocker S, Salowsky R, Leiber M, Gassmann M, Lightfoot S, Menzel W, Granzow M, Ragg T. 2006. The RIN: an RNA integrity number for assigning integrity values to RNA measurements. $B M C$ Molecular Biology 7: 3.

Sehr EM, Agusti J, Lehner R, Farmer EE, Schwarz M, Greb T. 2010. Analysis of secondary growth in the Arabidopsis shoot reveals a positive role of jasmonate signalling in cambium formation. Plant Journal 63: 811-822.

Seifert GJ, Roberts K. 2007. The biology of arabinogalactan proteins. Annual Review of Plant Biology 58: 137-161.

Smirnoff N. 2011. Vitamin C: the metabolism and functions of ascorbic acid in plants. Advances in Botanical Research 59: 107-177. 
de Souza A, Hull PA, Gille S, Pauly M. 2014. Identification and functional characterization of the distinct plant pectin esterases PAE8 and PAE9 and their deletion mutants. Planta 240: 1123-1138.

Trapnell C, Pachter L, Salzberg SL. 2009. TopHat: discovering splice junctions with RNA-Seq. Bioinformatics 25: 1105-1111.

Trapnell C, Williams BA, Pertea G, Mortazavi A, Kwan G, van Baren MJ, Salzberg SL, Wold BJ, Pachter L. 2010. Transcript assembly and quantification by RNA-Seq reveals unannotated transcripts and isoform switching during cell differentiation. Nature Biotechnology 28: 511-515.

Ukrainetz NK, Kang K-Y, Aitken SN, Stoehr M, Mansfield SD. 2008. Heritability and phenotypic and genetic correlations of coastal Douglas-fir (Pseudotsuga menziesii) wood quality traits. Canadian Journal of Forest Research 38: 1536-1546.

Vahala J, Felten J, Love J, Gorzsas A, Gerber L, Lamminmaki A, Kangasjarvi J, Sundberg B. 2013. A genome-wide screen for ethylene-induced ethylene response factors (ERFs) in hybrid aspen stem identifies ERF genes that modify stem growth and wood properties. New Phytologist 200: 511-522.

Washusen R, Evans R, Southerton S. 2005. A study of Eucalyptus grandis and Eucalyptus globulus branch wood microstructure. Iawa Journal 26: 203-210.

Washusen R, Ilic J, Waugh G. 2003. The relationship between longitudinal growth strain, tree form and tension wood at the stem periphery of ten- to eleven-year-old Eucalyptus globulus labill. Holzforschung 57: 308-316.

Wolucka BA, Van Montagu M. 2003. GDP-Mannose 3',5'-Epimerase forms GDP-L-gulose, a putative intermediate for the de novo biosynthesis of vitamin C in plants. Journal of Biological Chemistry 278: 47483-47490.

Yamamoto H. 2004. Role of the gelatinous layer on the origin of the physical properties of the tension wood. Journal of Wood Science 50: 197-208.

Yin Y, Mao X, Yang J, Chen X, Mao F, Xu Y. 2012. DbCAN: a web resource for automated carbohydrate-active enzyme annotation. Nucleic Acids Research 40 (W1): W445-W451.

Yokoyama T, Kadla J, Chang H. 2002. Microanalytical method for the characterization of fiber components and morphology of woody plants. Journal of Agricultural and Food Chemistry 50: 1040-1044.

Yoshida M, Ohta H, Yamamoto H, Okuyama T. 2002. Tensile growth stress and lignin distribution in the cell walls of yellow poplar, Liriodendron tulipifera Linn. Trees - Structure and Function 16: 457-464.

Yoshizawa N, Inami A, Miyake S, Ishiguri F, Yokota S. 2000. Anatomy and lignin distribution of reaction wood in two Magnolia species. Wood Science and Technology 34: 183-196.

Zhao Y, Song D, Sun J, Li L. 2013. Populus endo-beta-mannanase PtrMAN6 plays a role in coordinating cell wall remodeling with suppression of secondary wall thickening through generation of oligosaccharide signals. Plant Journal 74: 473-485. 


\section{Supporting Information}

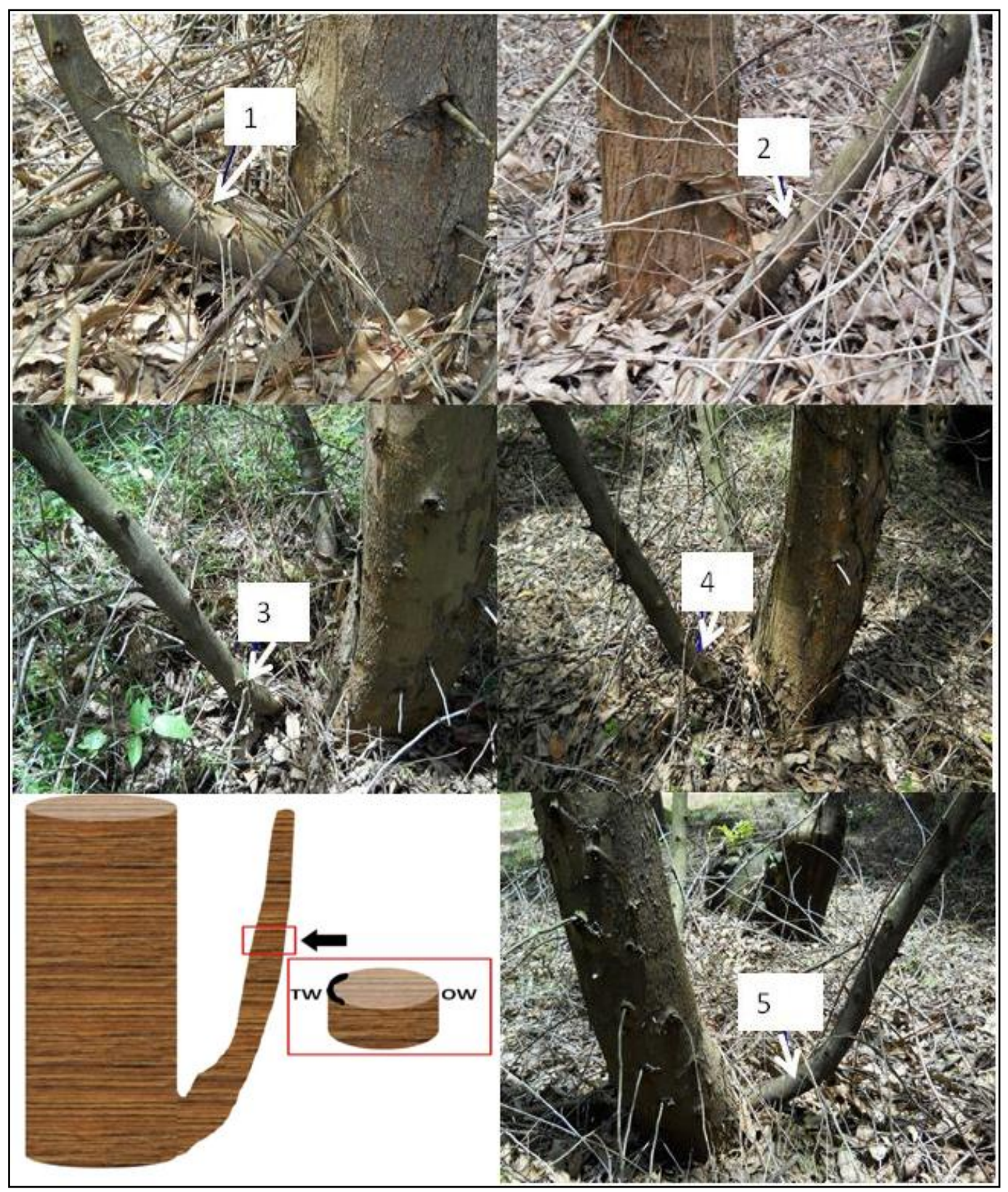

Fig. S1 Trees used for analysis of physicochemical changes in tension wood properties. Five individuals (ramets) of a commercial hybrid Eucalyptus grandis $\times$ E. urophylla $\mathrm{F}_{1}$ hybrid clone (GUSAP1) were selected with naturally slanting branches emerging from the base of the tree. A transverse disc (bottom left) was cut from an area of the branch which was at approximately $45^{\circ}$ from the longitudinal axis of the tree trunk. TW, tension wood; OW, opposite wood. 

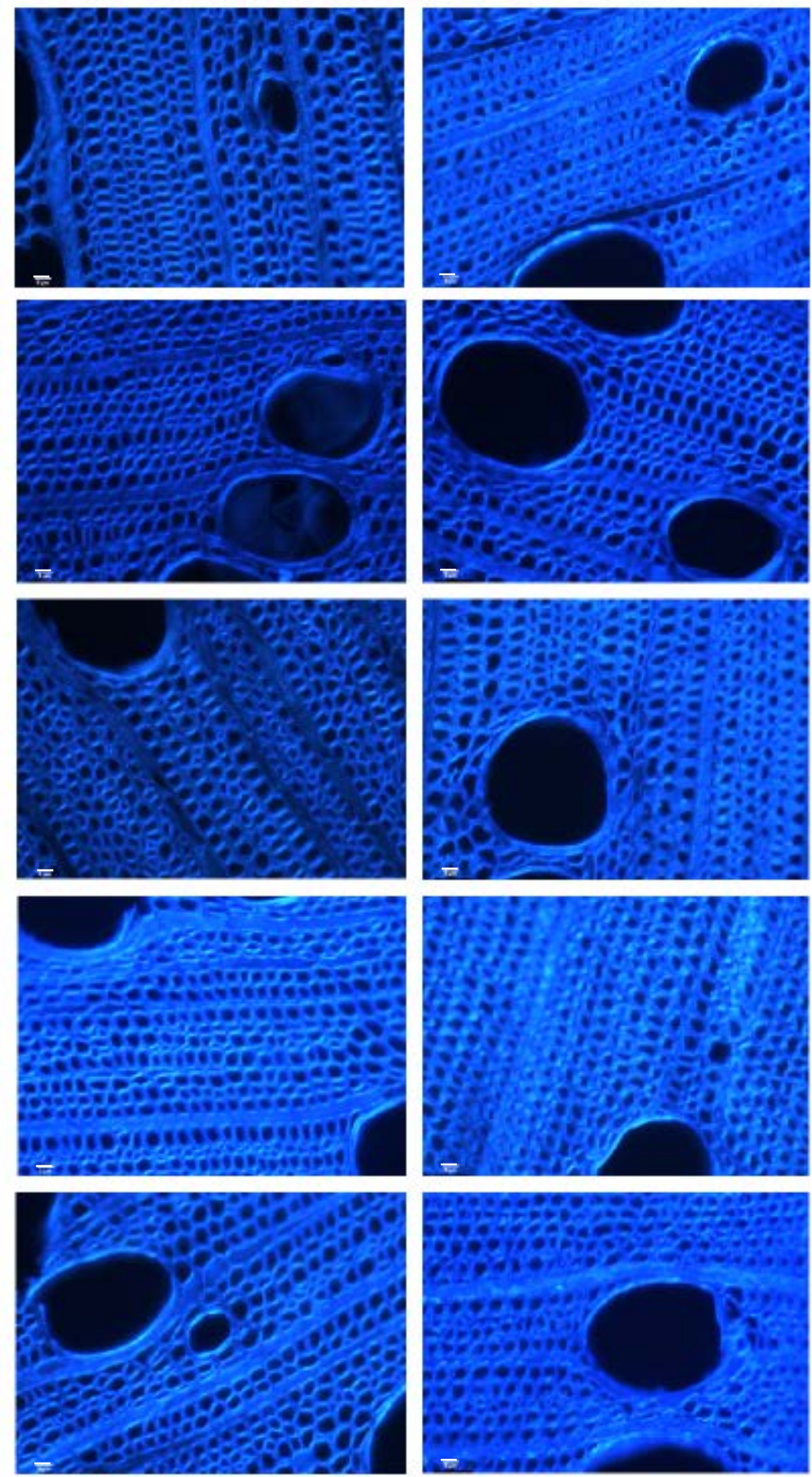

Fig. S2 Comparison of opposite wood (left) and tension wood (right) tissue from five ramets (top

to bottom, 1-5 from Supporting Information Fig. S1) of an $F_{1}$ hybrid clone of Eucalyptus grandis and E. urophylla (GUSAP1). Bar, $5 \mu \mathrm{m}$. 


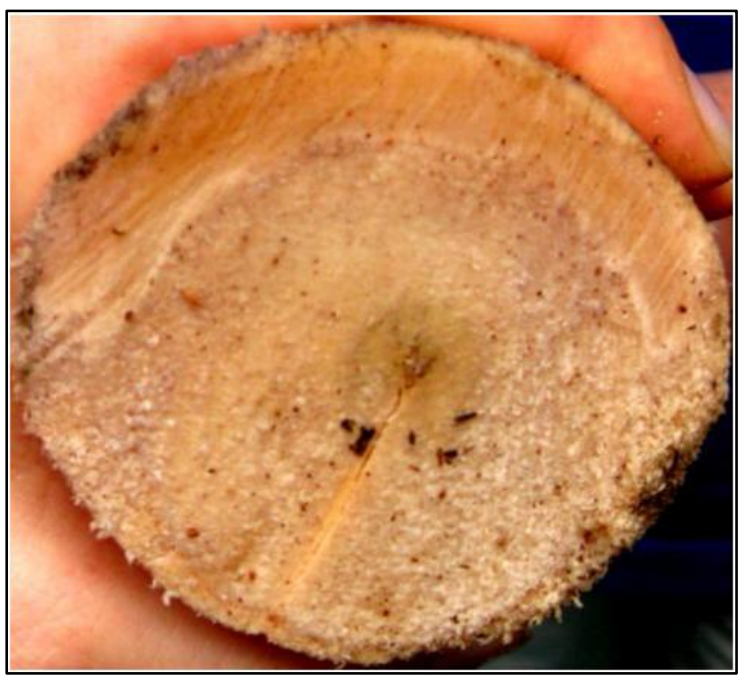

Fig. S3 Cross section of the main stem of an 18-month-old GUSAP1 (E. grandis $\times$ E. urophylla) tree after 6 months of bending. Tension wood can be seen at a macroscopic level on the top half of the bent trunk. 


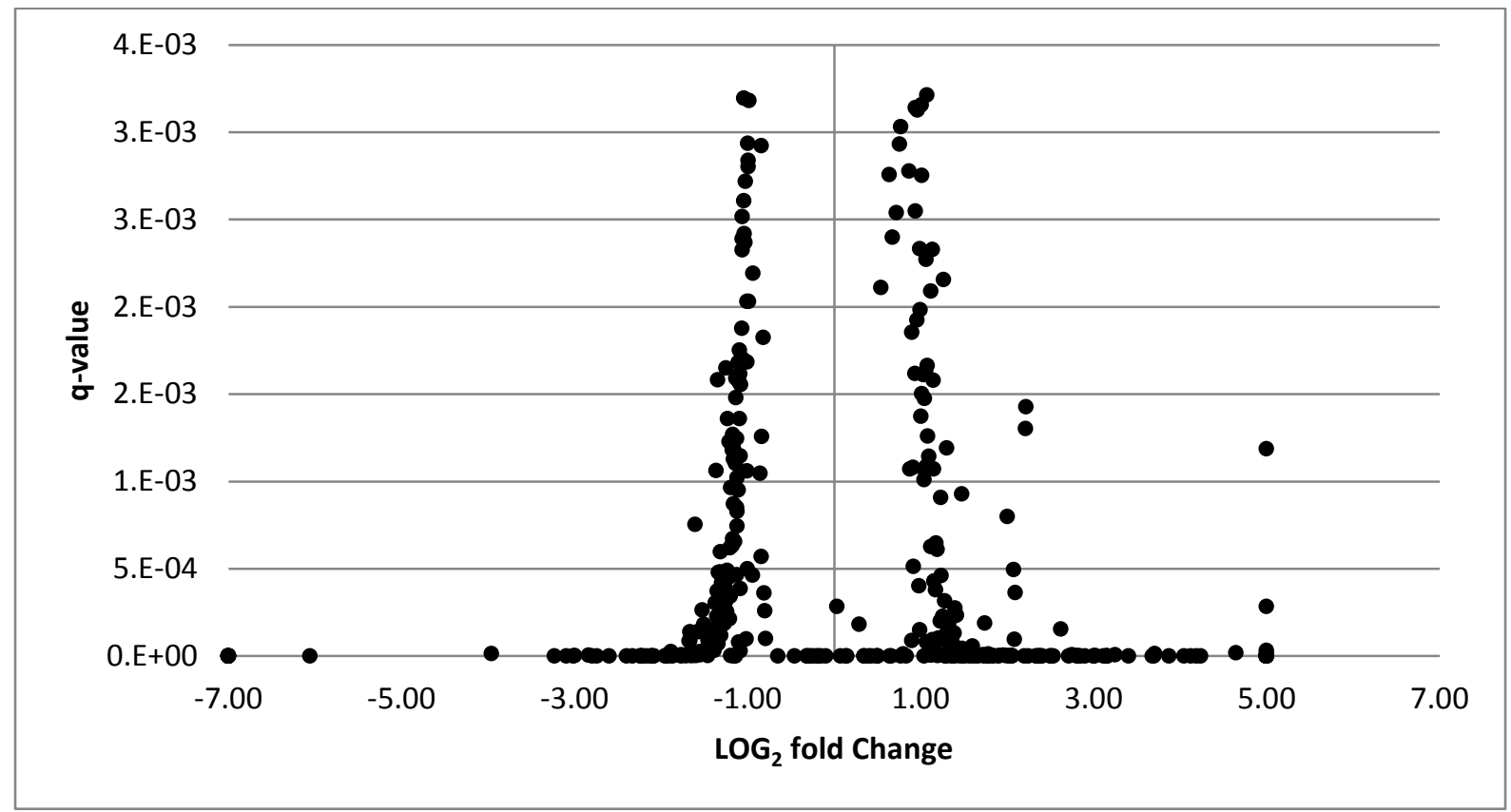

Fig. S4 Volcano plot of significantly differentially expressed genes in 3-wk tension wood vs upright control. 


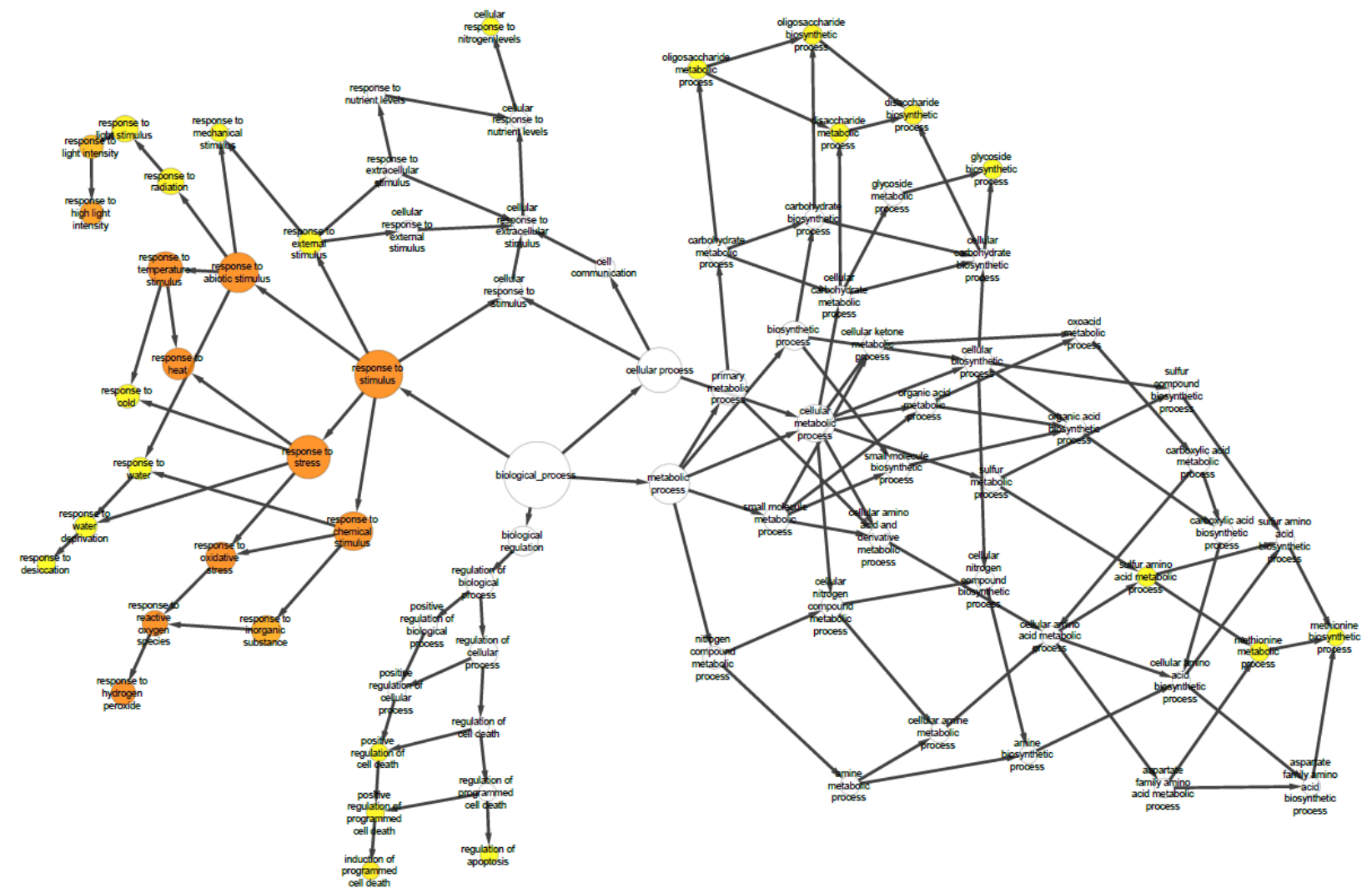

Fig. S5 Significantly enriched gene ontology (GO) terms in differentially upregulated genes in induced tension wood xylem compared with upright control xylem. 


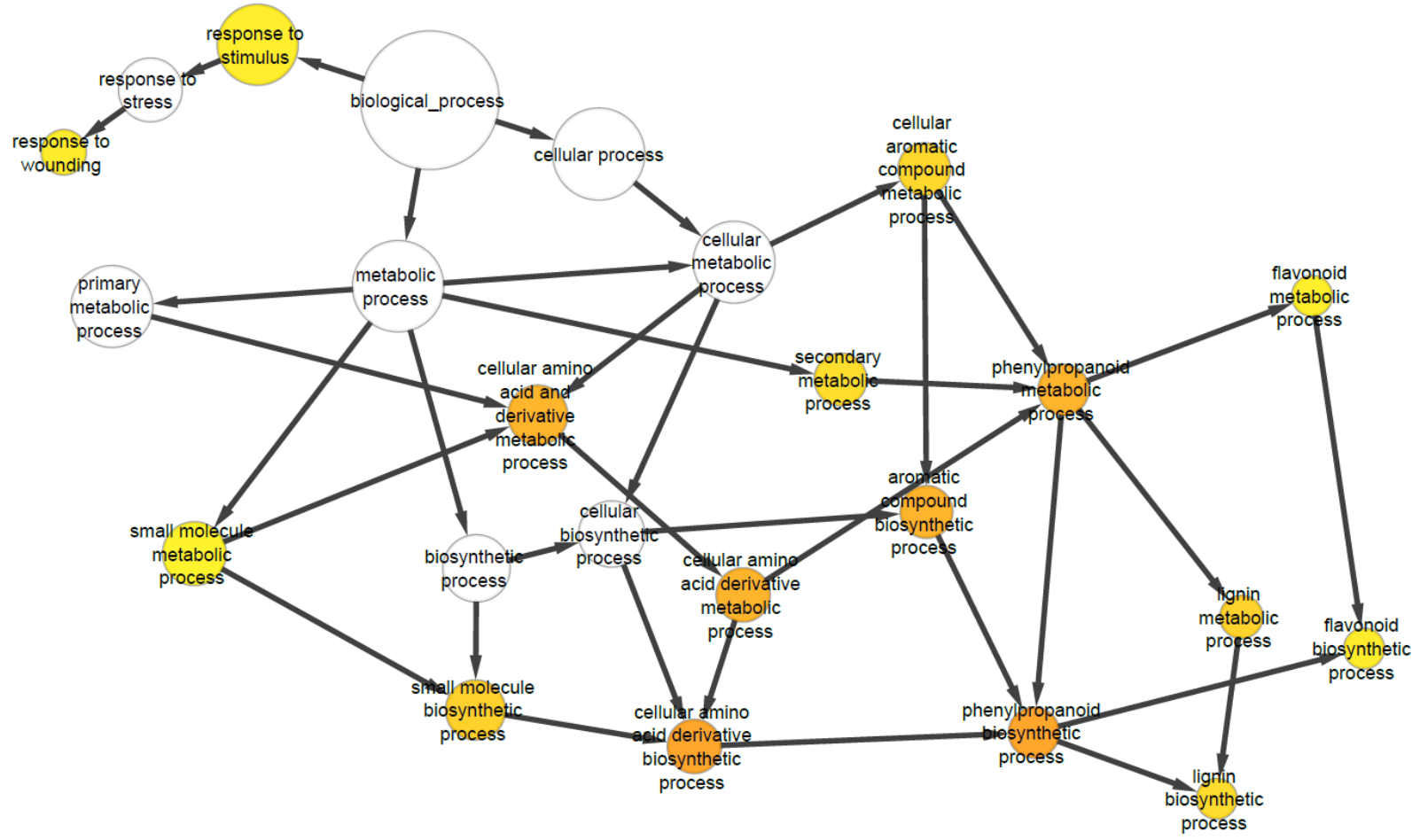

Fig. S6 Significantly enriched gene ontology (GO) terms in differentially downregulated genes in induced tension wood xylem compared with upright control xylem. 


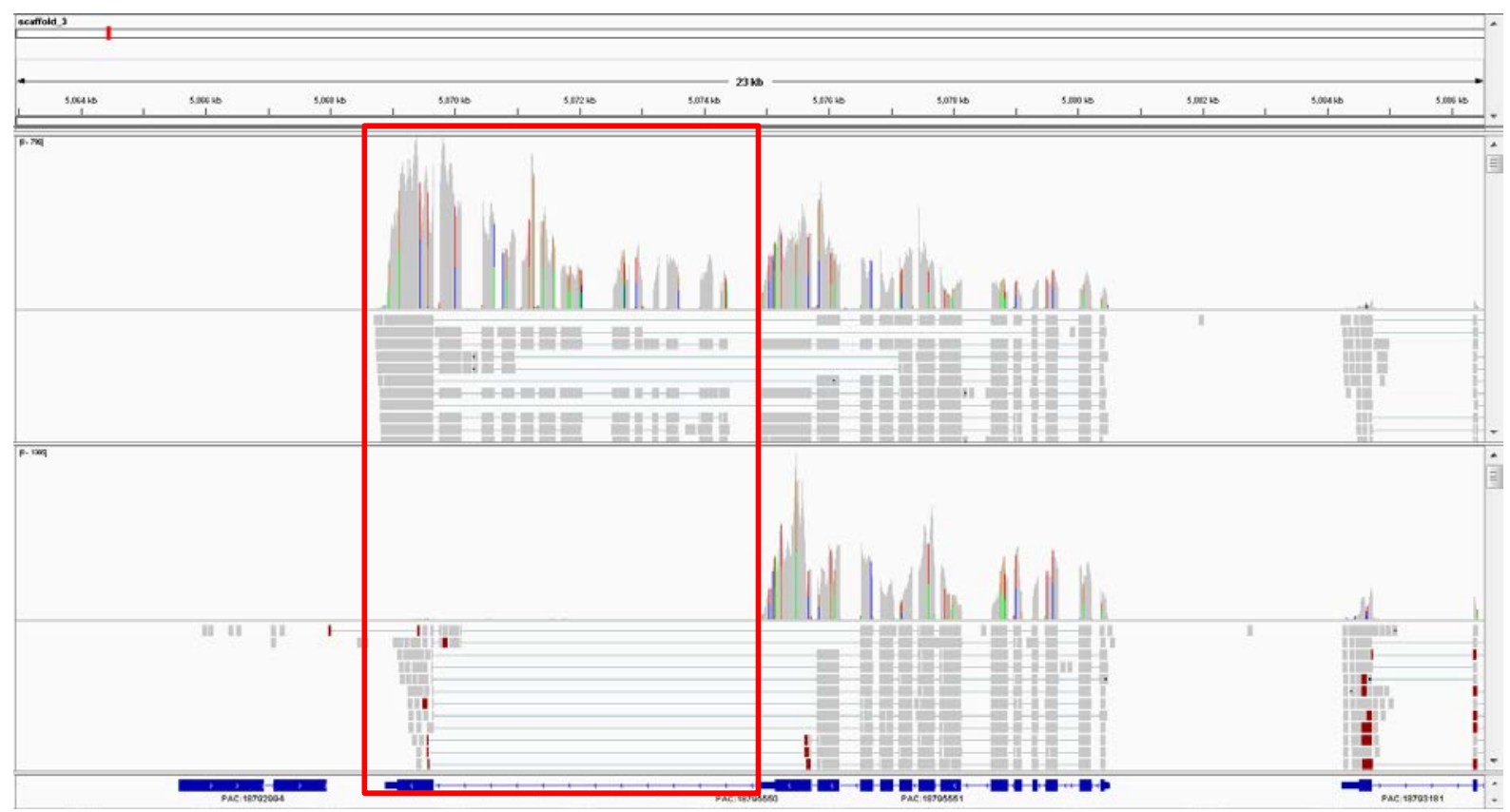

Fig. S7 Evidence for tension wood-specific expression of a tandem gene copy of a secondary cell wall cellulose synthase gene. The genomic region of the paralogous cellulose synthase gene expressed in tension wood (top) and not in the upright control (bottom) is highlighted in the red box. The sequence of this paralog was interrogated and predicts a full length in-frame duplicate of EgCesA3, as annotated by Ranik \& Myburg, 2006.

Ranik M, Myburg AA. 2006. Six new cellulose synthase genes from Eucalyptus are associated with primary and secondary cell wall biosynthesis. Tree Physiology 26: 545-556. 
Table S1 Numbers of mRNA-seq reads mapping to Eucalyptus grandis genome

\begin{tabular}{lll}
\hline Tissue type & Sample ID & Mapped reads \\
\hline Tensionwood & tensionwood1 & $8,779,533$ \\
Tensionwood & tensionwood2 & $8,099,046$ \\
Tensionwood & tensionwood3 & $9,830,430$ \\
Xylem & upright1 & $19,053,227$ \\
Xylem & upright2 & $19,876,244$ \\
Xylem & upright3 & $12,368,913$ \\
\hline
\end{tabular}


Table S2 Summary of relative changes in microfibril angle (MFA), lignin, and cell wall sugars in tension wood compared with opposite wood in five trees

\begin{tabular}{|c|c|c|c|c|c|c|c|}
\hline Tree & $\begin{array}{l}\Delta \text { MFA } \\
\text { in TW }\end{array}$ & $\begin{array}{l}\Delta \% \\
\text { Insoluble } \\
\text { lignin }\end{array}$ & $\begin{array}{l}\Delta \% \\
\text { Lignin }\end{array}$ & $\Delta$ Galactose & $\Delta$ Glucose & $\Delta$ Xylose & $\Delta$ Mannose \\
\hline 1 & $8.91 \%$ & $0.04 \%$ & $0.46 \%$ & $170.37 \%$ & $13.70 \%$ & $-16.43 \%$ & $-34.47 \%$ \\
\hline 2 & $-7.25 \%$ & $-6.71 \%$ & $-5.53 \%$ & $151.83 \%$ & $16.16 \%$ & $-17.02 \%$ & $-26.44 \%$ \\
\hline 3 & $-13.96 \%$ & $-4.85 \%$ & $-4.43 \%$ & $198.28 \%$ & $14.84 \%$ & $-22.13 \%$ & $-46.86 \%$ \\
\hline 4 & $-10.19 \%$ & $-3.36 \%$ & $-2.80 \%$ & $298.24 \%$ & $9.16 \%$ & $-26.64 \%$ & $-40.70 \%$ \\
\hline 5 & $-2.63 \%$ & $-6.83 \%$ & $-6.75 \%$ & $267.49 \%$ & $27.70 \%$ & $-10.26 \%$ & $-31.12 \%$ \\
\hline MEAN & $-5.02 \%$ & $-4.34 \%$ & $-3.81 \%$ & $217.24 \%$ & $16.31 \%$ & $-18.50 \%$ & $-35.92 \%$ \\
\hline SD & $8.82 \%$ & $2.84 \%$ & $2.79 \%$ & $63.09 \%$ & $6.89 \%$ & $6.20 \%$ & $8.02 \%$ \\
\hline SE & $3.95 \%$ & $1.27 \%$ & $1.25 \%$ & $28.21 \%$ & $3.08 \%$ & $2.77 \%$ & $3.59 \%$ \\
\hline
\end{tabular}

TW, tension wood. 
Table S3 Relative changes in holocellulose, $\alpha$-cellulose and total glucose in tension wood compared with opposite wood in five trees

\begin{tabular}{llll}
\hline Tree & $\mathbf{\Delta \%}$ Holocellulose & $\boldsymbol{\Delta} \% \boldsymbol{\alpha}$-cellulose & $\boldsymbol{\Delta} \%$ Glucose \\
\hline 1 & $-0.02 \%$ & $9.32 \%$ & $13.70 \%$ \\
2 & $-1.73 \%$ & $1.79 \%$ & $16.16 \%$ \\
3 & $2.16 \%$ & $12.44 \%$ & $14.84 \%$ \\
4 & $6.71 \%$ & $6.09 \%$ & $9.16 \%$ \\
5 & $7.26 \%$ & $-0.82 \%$ & $27.70 \%$ \\
MEAN & $\mathbf{2 . 8 7 \%}$ & $\mathbf{5 . 7 7 \%}$ & $\mathbf{1 6 . 3 1 \%}$ \\
SD & $4.00 \%$ & $5.39 \%$ & $6.89 \%$ \\
SE & $1.79 \%$ & $2.41 \%$ & $3.08 \%$ \\
\hline
\end{tabular}


Table S6 GoToolBox analysis of 3 wk TW differentially expressed genes.

Upregulated - BP

\begin{tabular}{|c|c|c|c|c|}
\hline GO_ID & Level(s) & Term & $P$-value & $\begin{array}{c}\text { Enrichment } \\
\text { (E)/depletion } \\
\text { (D) }\end{array}$ \\
\hline GO:0009408 & 5,4 & response to heat & $2.67 \mathrm{E}-22$ & $E$ \\
\hline GO:0009266 & 4 & $\begin{array}{l}\text { response to } \\
\text { temperature } \\
\text { stimulus }\end{array}$ & 2.03E-20 & E \\
\hline GO:0009628 & 3 & $\begin{array}{l}\text { response to } \\
\text { abiotic stimulus }\end{array}$ & $4.20 \mathrm{E}-18$ & $\mathrm{E}$ \\
\hline GO:0050896 & 2 & $\begin{array}{l}\text { response to } \\
\text { stimulus }\end{array}$ & $3.08 \mathrm{E}-16$ & E \\
\hline GO:0006950 & 3 & $\begin{array}{l}\text { response to } \\
\text { stress }\end{array}$ & 4.73E-15 & $\mathrm{E}$ \\
\hline GO:0000302 & 5 & $\begin{array}{l}\text { response to } \\
\text { reactive oxygen } \\
\text { species }\end{array}$ & 2.38E-12 & $\mathrm{E}$ \\
\hline GO:0042542 & 6 & $\begin{array}{l}\text { response to } \\
\text { hydrogen } \\
\text { peroxide }\end{array}$ & $1.42 \mathrm{E}-11$ & $\mathrm{E}$ \\
\hline GO:0006979 & 4 & $\begin{array}{l}\text { response to } \\
\text { oxidative stress }\end{array}$ & $1.42 \mathrm{E}-11$ & E \\
\hline GO:0009644 & 7 & $\begin{array}{l}\text { response to high } \\
\text { light intensity }\end{array}$ & 2.83E-09 & $\mathrm{E}$ \\
\hline GO:0042221 & 3 & $\begin{array}{l}\text { response to } \\
\text { chemical } \\
\text { stimulus }\end{array}$ & 6.29E-09 & E \\
\hline GO:0009642 & 6 & $\begin{array}{l}\text { response to light } \\
\text { intensity }\end{array}$ & 7.58E-08 & E \\
\hline GO:0009416 & 5 & $\begin{array}{l}\text { response to light } \\
\text { stimulus }\end{array}$ & 8.57E-06 & E \\
\hline GO:0009314 & 4 & $\begin{array}{l}\text { response to } \\
\text { radiation }\end{array}$ & $1.08 \mathrm{E}-05$ & $\mathrm{E}$ \\
\hline GO:0009409 & 5,4 & response to cold & $5.44 \mathrm{E}-05$ & E \\
\hline GO:0009725 & 4 & $\begin{array}{l}\text { response to } \\
\text { hormone } \\
\text { stimulus }\end{array}$ & 8.19E-05 & E \\
\hline GO:0012502 & $8,6,7$ & $\begin{array}{l}\text { induction of } \\
\text { programmed } \\
\text { cell death }\end{array}$ & 1.13E-04 & E \\
\hline GO:0043068 & $7,5,6$ & $\begin{array}{l}\text { positive } \\
\text { regulation of } \\
\text { programmed } \\
\text { cell death }\end{array}$ & $1.57 \mathrm{E}-04$ & $\mathrm{E}$ \\
\hline
\end{tabular}




\begin{tabular}{|c|c|c|c|c|}
\hline GO:0009719 & 3 & $\begin{array}{l}\text { response to } \\
\text { endogenous } \\
\text { stimulus }\end{array}$ & $1.58 \mathrm{E}-04$ & $\mathrm{E}$ \\
\hline GO:0010942 & $6,4,5$ & $\begin{array}{l}\text { positive } \\
\text { regulation of } \\
\text { cell death }\end{array}$ & 2.09E-04 & $\mathrm{E}$ \\
\hline GO:0046351 & 6,7 & $\begin{array}{l}\text { disaccharide } \\
\text { biosynthetic } \\
\text { process }\end{array}$ & 3.35E-04 & $\mathrm{E}$ \\
\hline GO:0005984 & 5,6 & $\begin{array}{l}\text { disaccharide } \\
\text { metabolic } \\
\text { process }\end{array}$ & 6.95E-04 & $\mathrm{E}$ \\
\hline GO:0009612 & 4 & $\begin{array}{l}\text { response to } \\
\text { mechanical } \\
\text { stimulus }\end{array}$ & 8.76E-04 & $\mathrm{E}$ \\
\hline GO:0032502 & 2 & $\begin{array}{l}\text { developmental } \\
\text { process }\end{array}$ & 8.98E-04 & $\mathrm{E}$ \\
\hline GO:0042981 & 7,6 & $\begin{array}{l}\text { regulation of } \\
\text { apoptosis }\end{array}$ & $9.90 \mathrm{E}-04$ & $\mathrm{E}$ \\
\hline GO:0009414 & 5,4 & $\begin{array}{l}\text { response to } \\
\text { water } \\
\text { deprivation }\end{array}$ & $1.05 \mathrm{E}-03$ & $\mathrm{E}$ \\
\hline GO:0009269 & 6,5 & $\begin{array}{l}\text { response to } \\
\text { desiccation }\end{array}$ & $1.24 \mathrm{E}-03$ & $\mathrm{E}$ \\
\hline GO:0009415 & 4 & $\begin{array}{l}\text { response to } \\
\text { water }\end{array}$ & $1.40 \mathrm{E}-03$ & $\mathrm{E}$ \\
\hline GO:0032501 & 2 & $\begin{array}{l}\text { multicellular } \\
\text { organismal } \\
\text { process }\end{array}$ & $1.47 \mathrm{E}-03$ & $\mathrm{E}$ \\
\hline GO:0009605 & 3 & $\begin{array}{l}\text { response to } \\
\text { external } \\
\text { stimulus }\end{array}$ & 2.30E-03 & $\mathrm{E}$ \\
\hline GO:0007638 & 4,5 & $\begin{array}{l}\text { mechanosensory } \\
\text { behavior }\end{array}$ & 2.77E-03 & $\mathrm{E}$ \\
\hline GO:0010032 & 5,6 & $\begin{array}{l}\text { meiotic } \\
\text { chromosome } \\
\text { condensation }\end{array}$ & 2.77E-03 & $\mathrm{E}$ \\
\hline GO:0005992 & 7,8 & $\begin{array}{l}\text { trehalose } \\
\text { biosynthetic } \\
\text { process }\end{array}$ & $3.26 \mathrm{E}-03$ & $\mathrm{E}$ \\
\hline GO:0043067 & 6,5 & $\begin{array}{l}\text { regulation of } \\
\text { programmed } \\
\text { cell death }\end{array}$ & $3.26 \mathrm{E}-03$ & $\mathrm{E}$ \\
\hline GO:0010941 & 5,4 & $\begin{array}{l}\text { regulation of } \\
\text { cell death }\end{array}$ & 3.47E-03 & $\mathrm{E}$ \\
\hline GO:0005991 & 6,7 & trehalose & $3.90 \mathrm{E}-03$ & $\mathrm{E}$ \\
\hline
\end{tabular}




\begin{tabular}{|c|c|c|c|c|}
\hline & & $\begin{array}{l}\text { metabolic } \\
\text { process }\end{array}$ & & \\
\hline GO:0007017 & 3 & $\begin{array}{l}\text { microtubule- } \\
\text { based process }\end{array}$ & 4.60E-03 & $\mathrm{E}$ \\
\hline GO:0051707 & 3,4 & $\begin{array}{l}\text { response to } \\
\text { other organism }\end{array}$ & 4.75E-03 & $\mathrm{E}$ \\
\hline GO:0007169 & 8,7 & $\begin{array}{l}\text { transmembrane } \\
\text { receptor protein } \\
\text { tyrosine kinase } \\
\text { signaling } \\
\text { pathway }\end{array}$ & $5.22 \mathrm{E}-03$ & $\mathrm{E}$ \\
\hline GO:0007167 & 7,6 & $\begin{array}{l}\text { enzyme linked } \\
\text { receptor protein } \\
\text { signaling } \\
\text { pathway }\end{array}$ & $5.22 \mathrm{E}-03$ & $\mathrm{E}$ \\
\hline GO:0051316 & $10,9,5,8,4,7,6$ & $\begin{array}{l}\text { attachment of } \\
\text { spindle } \\
\text { microtubules to } \\
\text { kinetochore } \\
\text { during meiotic } \\
\text { chromosome } \\
\text { segregation }\end{array}$ & 5.52E-03 & $\mathrm{E}$ \\
\hline GO:0008608 & $9,8,5,7$ & $\begin{array}{l}\text { attachment of } \\
\text { spindle } \\
\text { microtubules to } \\
\text { kinetochore }\end{array}$ & 5.52E-03 & $\mathrm{E}$ \\
\hline GO:0045143 & $10,8,7,5,9,6,4$ & $\begin{array}{l}\text { homologous } \\
\text { chromosome } \\
\text { segregation }\end{array}$ & 5.52E-03 & $\mathrm{E}$ \\
\hline GO:0051313 & $8,7,4,6$ & $\begin{array}{l}\text { attachment of } \\
\text { spindle } \\
\text { microtubules to } \\
\text { chromosome }\end{array}$ & 5.52E-03 & $\mathrm{E}$ \\
\hline GO:0051754 & $7,11,9,5,10,8,4,6$ & $\begin{array}{l}\text { meiotic sister } \\
\text { chromatid } \\
\text { cohesion, } \\
\text { centromeric }\end{array}$ & 5.52E-03 & $\mathrm{E}$ \\
\hline GO:0051455 & $11,10,6,9,8,5,7$ & $\begin{array}{l}\text { attachment of } \\
\text { spindle } \\
\text { microtubules to } \\
\text { kinetochore } \\
\text { during meiosis I }\end{array}$ & 5.52E-03 & $\mathrm{E}$ \\
\hline GO:0034453 & $7,6,5$ & $\begin{array}{l}\text { microtubule } \\
\text { anchoring }\end{array}$ & 5.52E-03 & $\mathrm{E}$ \\
\hline GO:0000226 & 5,4 & $\begin{array}{l}\text { microtubule } \\
\text { cytoskeleton }\end{array}$ & $5.86 \mathrm{E}-03$ & $\mathrm{E}$ \\
\hline
\end{tabular}




\begin{tabular}{|c|c|c|c|c|}
\hline \multicolumn{5}{|c|}{ organization } \\
\hline GO:0048856 & 3 & $\begin{array}{l}\text { anatomical } \\
\text { structure } \\
\text { development }\end{array}$ & 5.87E-03 & $\mathrm{E}$ \\
\hline GO:0009607 & 3 & $\begin{array}{l}\text { response to } \\
\text { biotic stimulus }\end{array}$ & $6.79 \mathrm{E}-03$ & $\mathrm{E}$ \\
\hline GO:0009737 & 5 & $\begin{array}{l}\text { response to } \\
\text { abscisic acid } \\
\text { stimulus }\end{array}$ & 6.85E-03 & $\mathrm{E}$ \\
\hline GO:0008219 & 3 & cell death & 6.93E-03 & $\mathrm{E}$ \\
\hline GO:0016265 & 2 & death & 6.93E-03 & $\mathrm{E}$ \\
\hline GO:0009804 & 5,4 & $\begin{array}{l}\text { coumarin } \\
\text { metabolic } \\
\text { process }\end{array}$ & $8.26 \mathrm{E}-03$ & $\mathrm{E}$ \\
\hline GO:0009805 & 6,5 & $\begin{array}{l}\text { coumarin } \\
\text { biosynthetic } \\
\text { process }\end{array}$ & 8.26E-03 & $\mathrm{E}$ \\
\hline GO:0006555 & $7,8,6$ & $\begin{array}{l}\text { methionine } \\
\text { metabolic } \\
\text { process }\end{array}$ & 8.78E-03 & $\mathrm{E}$ \\
\hline GO:0051094 & $5,3,4$ & $\begin{array}{l}\text { positive } \\
\text { regulation of } \\
\text { developmental } \\
\text { process }\end{array}$ & $9.10 \mathrm{E}-03$ & $\mathrm{E}$ \\
\hline GO:0007166 & 6,5 & $\begin{array}{l}\text { cell surface } \\
\text { receptor linked } \\
\text { signal } \\
\text { transduction }\end{array}$ & 9.17E-03 & $\mathrm{E}$ \\
\hline GO:0042446 & 6,4 & $\begin{array}{l}\text { hormone } \\
\text { biosynthetic } \\
\text { process }\end{array}$ & 9.75E-03 & $\mathrm{E}$ \\
\hline GO:0034754 & 6,4 & $\begin{array}{l}\text { cellular } \\
\text { hormone } \\
\text { metabolic } \\
\text { process }\end{array}$ & $9.75 \mathrm{E}-03$ & $\mathrm{E}$ \\
\hline GO:0034961 & 6 & $\begin{array}{l}\text { cellular } \\
\text { biopolymer } \\
\text { biosynthetic } \\
\text { process }\end{array}$ & 6.97E-03 & $\mathrm{D}$ \\
\hline GO:0043284 & 5 & $\begin{array}{l}\text { biopolymer } \\
\text { biosynthetic } \\
\text { process }\end{array}$ & 6.73E-03 & $\mathrm{D}$ \\
\hline GO:0010467 & 4 & gene expression & 3.30E-03 & $\mathrm{D}$ \\
\hline
\end{tabular}


Upregulated - MF

\begin{tabular}{|c|c|c|c|c|}
\hline GO_ID & Level(s) & Term & $P$-value & $\begin{array}{c}\text { Enrichment } \\
\text { (E)/depletion (D) }\end{array}$ \\
\hline GO:0016684 & 4 & $\begin{array}{l}\text { oxidoreductase activity, } \\
\text { acting on peroxide as } \\
\text { acceptor }\end{array}$ & 5.76E-06 & E \\
\hline GO:0004601 & 3,5 & peroxidase activity & 5.76E-06 & E \\
\hline GO:0016209 & 2 & antioxidant activity & $1.06 \mathrm{E}-05$ & $\mathrm{E}$ \\
\hline GO:0016491 & 3 & oxidoreductase activity & 5.14E-05 & E \\
\hline GO:0004805 & 8 & $\begin{array}{l}\text { trehalose-phosphatase } \\
\text { activity }\end{array}$ & $6.22 \mathrm{E}-04$ & E \\
\hline GO:0019203 & 7 & $\begin{array}{l}\text { carbohydrate phosphatase } \\
\text { activity }\end{array}$ & 8.81E-04 & $\mathrm{E}$ \\
\hline GO:0005200 & 3 & $\begin{array}{l}\text { structural constituent of } \\
\text { cytoskeleton }\end{array}$ & 2.18E-03 & $\mathrm{E}$ \\
\hline GO:0046409 & 5 & $\begin{array}{l}\text { p-coumarate 3-hydroxylase } \\
\text { activity }\end{array}$ & 2.33E-03 & $\mathrm{E}$ \\
\hline GO:0043864 & 6 & $\begin{array}{l}\text { indoleacetamide hydrolase } \\
\text { activity }\end{array}$ & 2.33E-03 & $\mathrm{E}$ \\
\hline GO:0010349 & 6 & $\begin{array}{l}\text { L-galactose dehydrogenase } \\
\text { activity }\end{array}$ & 2.33E-03 & $\mathrm{E}$ \\
\hline GO:0008379 & 5,7 & $\begin{array}{l}\text { thioredoxin peroxidase } \\
\text { activity }\end{array}$ & 2.33E-03 & E \\
\hline GO:0005372 & 4 & water transporter activity & $3.29 \mathrm{E}-03$ & E \\
\hline GO:0015250 & 5,7 & water channel activity & $3.29 \mathrm{E}-03$ & $\mathrm{E}$ \\
\hline GO:0004679 & 8 & $\begin{array}{l}\text { AMP-activated protein } \\
\text { kinase activity }\end{array}$ & 4.64E-03 & E \\
\hline GO:0008705 & 7 & $\begin{array}{l}\text { methionine synthase } \\
\text { activity }\end{array}$ & $6.95 \mathrm{E}-03$ & E \\
\hline GO:0003871 & 7 & $\begin{array}{l}\text { 5- } \\
\text { methyltetrahydropteroyltri } \\
\text { glutamate-homocysteine S- } \\
\text { methyltransferase activity }\end{array}$ & 6.95E-03 & E \\
\hline GO:0080064 & 7 & $\begin{array}{l}\text { 4,4-dimethyl-9beta,19- } \\
\text { cyclopropylsterol-4alpha- } \\
\text { methyl oxidase activity }\end{array}$ & $6.95 \mathrm{E}-03$ & E \\
\hline GO:0004096 & 4,6 & catalase activity & $6.95 \mathrm{E}-03$ & $\mathrm{E}$ \\
\hline GO:0042085 & 6 & $\begin{array}{l}\text { 5- } \\
\text { methyltetrahydropteroyltri- } \\
\text { L-glutamate-dependent } \\
\text { methyltransferase activity }\end{array}$ & $6.95 \mathrm{E}-03$ & $\mathrm{E}$ \\
\hline GO:0042084 & 6 & $\begin{array}{l}\text { 5-methyltetrahydrofolate- } \\
\text { dependent } \\
\text { methyltransferase activity }\end{array}$ & 6.95E-03 & $\mathrm{E}$ \\
\hline
\end{tabular}




\begin{tabular}{|c|c|c|c|c|}
\hline GO:0016757 & 4 & $\begin{array}{l}\text { transferase activity, } \\
\text { transferring glycosyl groups }\end{array}$ & $7.00 \mathrm{E}-03$ & $\mathrm{E}$ \\
\hline GO:0010309 & 6 & $\begin{array}{l}\text { acireductone dioxygenase } \\
\text { [iron(II)-requiring] activity }\end{array}$ & 9.24E-03 & $\mathrm{E}$ \\
\hline GO:0004645 & 6 & phosphorylase activity & $9.24 \mathrm{E}-03$ & $\mathrm{E}$ \\
\hline GO:0051920 & 4,6 & peroxiredoxin activity & $9.24 \mathrm{E}-03$ & $\mathrm{E}$ \\
\hline GO:0003824 & 2 & catalytic activity & $9.57 \mathrm{E}-03$ & $\mathrm{E}$ \\
\hline
\end{tabular}

Upregulated - CC

\begin{tabular}{|c|c|c|c|c|}
\hline GO_ID & Level(s) & Term & $P$-value & $\begin{array}{l}\text { Enrichment (E)/depletion } \\
\text { (D) }\end{array}$ \\
\hline GO:0045298 & $10,9,8,7,6,4,5$ & $\begin{array}{l}\text { tubulin } \\
\text { complex }\end{array}$ & 2.04E-04 & E \\
\hline GO:0005829 & $8,7,6,5$ & cytosol & 7.13E-04 & E \\
\hline GO:0005792 & 8,7 & microsome & $9.82 \mathrm{E}-04$ & E \\
\hline GO:0042598 & 7,6 & $\begin{array}{l}\text { vesicular } \\
\text { fraction }\end{array}$ & 9.82E-04 & E \\
\hline GO:0005737 & $6,5,4$ & cytoplasm & $1.00 \mathrm{E}-03$ & $\mathrm{E}$ \\
\hline GO:0005626 & 5,4 & $\begin{array}{l}\text { insoluble } \\
\text { fraction }\end{array}$ & 1.39E-03 & E \\
\hline GO:0005624 & 6,5 & $\begin{array}{l}\text { membrane } \\
\text { fraction }\end{array}$ & 1.39E-03 & $\mathrm{E}$ \\
\hline GO:0005874 & $10,9,8,7,6,5$ & microtubule & $1.48 \mathrm{E}-03$ & $\mathrm{E}$ \\
\hline GO:0010319 & $11,10,9,8,7,6,5$ & stromule & $1.77 \mathrm{E}-03$ & E \\
\hline GO:0000267 & 4,3 & cell fraction & $1.87 \mathrm{E}-03$ & E \\
\hline GO:0044444 & $7,6,5,4$ & $\begin{array}{l}\text { cytoplasmic } \\
\text { part }\end{array}$ & 2.17E-03 & $\mathrm{E}$ \\
\hline GO:0044424 & $5,4,3$ & $\begin{array}{l}\text { intracellular } \\
\text { part }\end{array}$ & 2.19E-03 & $\mathrm{E}$ \\
\hline GO:0005622 & 4,3 & intracellular & 2.30E-03 & E \\
\hline GO:0044430 & $9,8,7,6,5,4$ & $\begin{array}{l}\text { cytoskeletal } \\
\text { part }\end{array}$ & 3.80E-03 & $\mathrm{E}$ \\
\hline GO:0005856 & $8,7,6,5$ & cytoskeleton & $5.68 \mathrm{E}-03$ & E \\
\hline GO:0048196 & 5,4 & $\begin{array}{l}\text { middle lamella- } \\
\text { containing } \\
\text { extracellular } \\
\text { matrix }\end{array}$ & 7.12E-03 & E \\
\hline GO:0005876 & $11,9,10,8,7,6$ & $\begin{array}{l}\text { spindle } \\
\text { microtubule }\end{array}$ & 8.88E-03 & E \\
\hline GO:0008278 & $10,9,8,7,6,4,5$ & $\begin{array}{l}\text { cohesin } \\
\text { complex }\end{array}$ & 8.88E-03 & $\mathrm{E}$ \\
\hline GO:0012505 & 4,3 & $\begin{array}{l}\text { endomembrane } \\
\text { system }\end{array}$ & $1.82 \mathrm{E}-03$ & D \\
\hline
\end{tabular}


Downregulated - BP

\begin{tabular}{|c|c|c|c|c|}
\hline GO_ID & Level(s) & Term & $P$-value & $\begin{array}{c}\text { Enrichment (E)/depletion } \\
\text { (D) }\end{array}$ \\
\hline GO:0042398 & 6,5 & $\begin{array}{l}\text { cellular amino acid } \\
\text { derivative } \\
\text { biosynthetic process }\end{array}$ & 5.59E-11 & ( \\
\hline GO:0009699 & $7,6,5$ & $\begin{array}{l}\text { phenylpropanoid } \\
\text { biosynthetic process }\end{array}$ & $5.69 \mathrm{E}-10$ & $\mathrm{E}$ \\
\hline GO:0006575 & 5 & $\begin{array}{l}\text { cellular amino acid } \\
\text { derivative } \\
\text { metabolic process }\end{array}$ & 1.14E-09 & $\mathrm{E}$ \\
\hline GO:0019438 & 5 & $\begin{array}{l}\text { aromatic compound } \\
\text { biosynthetic process }\end{array}$ & 1.86E-09 & $\mathrm{E}$ \\
\hline GO:0009698 & $6,5,4$ & $\begin{array}{l}\text { phenylpropanoid } \\
\text { metabolic process }\end{array}$ & 5.04E-09 & $\mathrm{E}$ \\
\hline GO:0006519 & 4 & $\begin{array}{l}\text { cellular amino acid } \\
\text { and derivative } \\
\text { metabolic process }\end{array}$ & 5.44E-09 & $\mathrm{E}$ \\
\hline GO:0006725 & 4 & $\begin{array}{l}\text { cellular aromatic } \\
\text { compound } \\
\text { metabolic process }\end{array}$ & 5.56E-07 & $\mathrm{E}$ \\
\hline GO:0009611 & 4 & $\begin{array}{l}\text { response to } \\
\text { wounding }\end{array}$ & 7.64E-07 & $\mathrm{E}$ \\
\hline GO:0019748 & 3 & $\begin{array}{l}\text { secondary } \\
\text { metabolic process }\end{array}$ & 9.69E-07 & $\mathrm{E}$ \\
\hline GO:0009809 & $8,7,6$ & $\begin{array}{l}\text { lignin biosynthetic } \\
\text { process }\end{array}$ & 6.65E-06 & $\mathrm{E}$ \\
\hline GO:0009605 & 3 & $\begin{array}{l}\text { response to external } \\
\text { stimulus }\end{array}$ & 2.07E-05 & $\mathrm{E}$ \\
\hline GO:0009808 & $7,6,5$ & $\begin{array}{l}\text { lignin metabolic } \\
\text { process }\end{array}$ & 2.90E-05 & $\mathrm{E}$ \\
\hline GO:0050896 & 2 & $\begin{array}{l}\text { response to } \\
\text { stimulus }\end{array}$ & 3.59E-05 & $\mathrm{E}$ \\
\hline GO:0009813 & $8,7,6$ & $\begin{array}{l}\text { flavonoid } \\
\text { biosynthetic process }\end{array}$ & 7.37E-05 & $\mathrm{E}$ \\
\hline GO:0009812 & $7,6,5$ & $\begin{array}{l}\text { flavonoid metabolic } \\
\text { process }\end{array}$ & 1.15E-04 & $\mathrm{E}$ \\
\hline GO:0009416 & 5 & $\begin{array}{l}\text { response to light } \\
\text { stimulus }\end{array}$ & 2.42E-04 & $\mathrm{E}$ \\
\hline GO:0009628 & 3 & $\begin{array}{l}\text { response to abiotic } \\
\text { stimulus }\end{array}$ & 2.55E-04 & $\mathrm{E}$ \\
\hline GO:0009314 & 4 & $\begin{array}{l}\text { response to } \\
\text { radiation }\end{array}$ & 2.93E-04 & $\mathrm{E}$ \\
\hline GO:0006949 & $4,3,6,5$ & $\begin{array}{l}\text { syncytium } \\
\text { formation }\end{array}$ & 4.99E-04 & $\mathrm{E}$ \\
\hline
\end{tabular}




\begin{tabular}{|c|c|c|c|c|}
\hline GO:0006807 & 3 & $\begin{array}{l}\text { nitrogen compound } \\
\text { metabolic process }\end{array}$ & 7.04E-04 & $\mathrm{E}$ \\
\hline GO:0009719 & 3 & $\begin{array}{l}\text { response to } \\
\text { endogenous } \\
\text { stimulus }\end{array}$ & 7.46E-04 & $\mathrm{E}$ \\
\hline GO:0009411 & 6 & response to UV & $1.24 \mathrm{E}-03$ & $\mathrm{E}$ \\
\hline GO:0034641 & 4 & $\begin{array}{l}\text { cellular nitrogen } \\
\text { compound } \\
\text { metabolic process }\end{array}$ & 1.99E-03 & $\mathrm{E}$ \\
\hline GO:0042221 & 3 & $\begin{array}{l}\text { response to } \\
\text { chemical stimulus }\end{array}$ & 2.98E-03 & $\mathrm{E}$ \\
\hline GO:0042180 & 4 & $\begin{array}{l}\text { cellular ketone } \\
\text { metabolic process }\end{array}$ & 3.39E-03 & $\mathrm{E}$ \\
\hline GO:0009714 & $7,6,5$ & $\begin{array}{l}\text { chalcone metabolic } \\
\text { process }\end{array}$ & 3.39E-03 & $\mathrm{E}$ \\
\hline GO:0000072 & $7,6,4$ & $\begin{array}{l}\text { M phase specific } \\
\text { microtubule } \\
\text { process }\end{array}$ & 3.39E-03 & $\mathrm{E}$ \\
\hline GO:0009715 & $8,7,6$ & $\begin{array}{l}\text { chalcone } \\
\text { biosynthetic process }\end{array}$ & 3.39E-03 & $\mathrm{E}$ \\
\hline GO:0019695 & 8 & $\begin{array}{l}\text { choline metabolic } \\
\text { process }\end{array}$ & 3.39E-03 & $\mathrm{E}$ \\
\hline GO:0042181 & 5 & $\begin{array}{l}\text { ketone biosynthetic } \\
\text { process }\end{array}$ & 3.39E-03 & $\mathrm{E}$ \\
\hline GO:0042425 & $8,9,7$ & $\begin{array}{l}\text { choline biosynthetic } \\
\text { process }\end{array}$ & 3.39E-03 & $\mathrm{E}$ \\
\hline GO:0017038 & $5,6,7$ & protein import & 3.98E-03 & $\mathrm{E}$ \\
\hline GO:0009725 & 4 & $\begin{array}{l}\text { response to } \\
\text { hormone stimulus }\end{array}$ & 5.21E-03 & $\mathrm{E}$ \\
\hline GO:0006950 & 3 & response to stress & 5.66E-03 & $\mathrm{E}$ \\
\hline GO:0009853 & 5 & photorespiration & 5.74E-03 & $\mathrm{E}$ \\
\hline GO:0009828 & 7 & $\begin{array}{l}\text { plant-type cell wall } \\
\text { loosening }\end{array}$ & 6.07E-03 & $\mathrm{E}$ \\
\hline GO:0009308 & 5 & $\begin{array}{l}\text { cellular amine } \\
\text { metabolic process }\end{array}$ & 6.37E-03 & $\mathrm{E}$ \\
\hline GO:0010224 & 7 & response to UV-B & 6.75E-03 & $\mathrm{E}$ \\
\hline GO:0042886 & 4,5 & amide transport & 6.75E-03 & $\mathrm{E}$ \\
\hline GO:0006656 & $7,8,9$ & $\begin{array}{l}\text { phosphatidylcholine } \\
\text { biosynthetic process }\end{array}$ & 6.75E-03 & $\mathrm{E}$ \\
\hline GO:0015840 & 5,6 & urea transport & 6.75E-03 & $\mathrm{E}$ \\
\hline GO:0042439 & 7 & $\begin{array}{l}\text { ethanolamine and } \\
\text { derivative } \\
\text { metabolic process }\end{array}$ & 6.75E-03 & $\mathrm{E}$ \\
\hline GO:0042440 & 3 & $\begin{array}{l}\text { pigment metabolic } \\
\text { process }\end{array}$ & 6.77E-03 & $\mathrm{E}$ \\
\hline
\end{tabular}




\begin{tabular}{|c|c|c|c|c|}
\hline GO:0044271 & 5 & $\begin{array}{l}\text { nitrogen compound } \\
\text { biosynthetic process }\end{array}$ & 7.46E-03 & $\mathrm{E}$ \\
\hline GO:0042545 & 5 & $\begin{array}{l}\text { cell wall } \\
\text { modification }\end{array}$ & 9.64E-03 & $\mathrm{E}$ \\
\hline GO:0043412 & 5 & $\begin{array}{l}\text { biopolymer } \\
\text { modification }\end{array}$ & 7.47E-03 & $\mathrm{D}$ \\
\hline GO:0044260 & 4 & $\begin{array}{l}\text { cellular } \\
\text { macromolecule } \\
\text { metabolic process }\end{array}$ & 7.10E-03 & $\mathrm{D}$ \\
\hline GO:0034960 & 5 & $\begin{array}{l}\text { cellular biopolymer } \\
\text { metabolic process }\end{array}$ & 4.73E-03 & $\mathrm{D}$ \\
\hline GO:0019538 & 5,4 & $\begin{array}{l}\text { protein metabolic } \\
\text { process }\end{array}$ & 3.15E-03 & $\mathrm{D}$ \\
\hline GO:0044267 & 6,5 & $\begin{array}{l}\text { cellular protein } \\
\text { metabolic process }\end{array}$ & 2.57E-04 & $\mathrm{D}$ \\
\hline
\end{tabular}

Downregulated - MF

No significant results

Downregulated - CC

\begin{tabular}{|cclcc}
\hline GO_ID & Level(s) & Term & P-value & $\begin{array}{c}\text { Enrichment } \\
\text { (E)/depletion (D) }\end{array}$ \\
\hline GO:0005783 & $8,7,6,5$ & $\begin{array}{l}\text { endoplasmic } \\
\text { reticulum }\end{array}$ & $5.14 \mathrm{E}-06$ & $\mathrm{E}$ \\
\hline GO:0009527 & $12,11,10,9,7,8,6,5$ & $\begin{array}{l}\text { plastid outer } \\
\text { membrane } \\
\text { plant-type cell }\end{array}$ & $2.72 \mathrm{E}-03$ & $\mathrm{E}$ \\
\hline GO:0009505 & 6,5 & $\begin{array}{l}\text { wall } \\
\text { photosystem II } \\
\text { antenna } \\
\text { complex }\end{array}$ & $4.87 \mathrm{E}-03$ & $\mathrm{E}$ \\
\hline GO:0009783 & $8,6,7,5,4$ & $\begin{array}{l}\text { organelle outer } \\
\text { membrane }\end{array}$ & $8.52 \mathrm{E}-03$ & $\mathrm{E}$ \\
\hline GO:0031968 & $9,8,6,7,5,4$ & $\begin{array}{l}\text { respiratory } \\
\text { chain complex }\end{array}$ & $8.80 \mathrm{E}-03$ & $\mathrm{E}$ \\
\hline I & $7,6,5$ & $\begin{array}{l}\text { NADH } \\
\text { dehydrogenase } \\
\text { complex }\end{array}$ & $8.80 \mathrm{E}-03$ & $\mathrm{E}$ \\
\hline GO:0030964 & $6,5,4$ & $\begin{array}{l}\text { outer } \\
\text { membrane } \\
\text { integral to } \\
\text { chloroplast } \\
\text { outer } \\
\text { membrane }\end{array}$ & $9.66 \mathrm{E}-03$ & $\mathrm{E}$ \\
\hline GO:0019867 & 5,4 & $9.70 \mathrm{E}-03$ & $\mathrm{E}$ \\
\hline GO:0031359 & $14,13,11,12,10,9,8,7,03$ & \\
\hline
\end{tabular}




\begin{tabular}{cclll} 
GO:0031351 & $10,12,11,9,8,7,6,5$ & $\begin{array}{l}\text { integral to } \\
\text { plastid } \\
\text { membrane }\end{array}$ & $9.70 \mathrm{E}-03$ & $\mathrm{E}$ \\
\hline $\mathrm{GO} 0031355$ & $11,13,12,10,9,8,7,6$ & $\begin{array}{l}\text { integral to } \\
\text { plastid outer } \\
\text { membrane } \\
\text { endomembrane } \\
\text { system }\end{array}$ & $9.70 \mathrm{E}-03$ & $\mathrm{E}$ \\
\hline $\mathrm{GO} 0012505$ & 4,3 & $2.75 \mathrm{E}-03$ & $\mathrm{D}$ \\
\hline
\end{tabular}


Table S7 Differential expression values (fragments per kilobase of coding sequence per million mapped fragments, FPKM) and relative fold-change in tension wood compared with upright control for all genes involved in the monolignol biosynthesis pathway in Eucalyptus (annotation according to V. Carocha et al., in preparation)

\begin{tabular}{|c|c|c|c|c|c|c|c|}
\hline PAL & E. grandis ID & $\begin{array}{c}\text { Average } \\
\text { FPKM } \\
\text { (upright) }\end{array}$ & $\begin{array}{c}\text { Average } \\
\text { FPKM } \\
\text { (TW) }\end{array}$ & $\begin{array}{l}\text { Ln (fold } \\
\text { change) }\end{array}$ & $P$-value & $q$-value & Significant \\
\hline PAL1 & Eucgr.A01144 & 0 & 0 & 0.04 & 0.965 & 1 & No \\
\hline PAL2 & Eucgr.C03570 & 0 & 2 & 3.70 & 0.0004 & 1 & No \\
\hline PAL3 & Eucgr.G02848 & 221 & 154 & -0.36 & 0.4891 & 0.9336 & No \\
\hline PAL4 & Eucgr.G02849 & 26 & 27 & 0.04 & 0.9077 & 1.0036 & No \\
\hline PAL5 & Eucgr.G02850 & 54 & 33 & -0.49 & 0.1354 & 0.5748 & No \\
\hline PAL6 & Eucgr.G02851 & 10 & 14 & 0.26 & 0.4178 & 1 & No \\
\hline PAL7 & Eucgr.G02852 & 70 & 54 & -0.26 & 0.4164 & 0.9036 & No \\
\hline PAL8 & Eucgr.J00907 & 50 & 15 & -1.23 & 0.0005 & 0.0104 & Yes \\
\hline PAL9 & Eucgr.J01079 & 491 & 253 & -0.66 & 0.7596 & 0.9987 & No \\
\hline C4H & E. grandis ID & $\begin{array}{c}\text { Average } \\
\text { FPKM } \\
\text { (upright) }\end{array}$ & $\begin{array}{c}\text { Average } \\
\text { FPKM } \\
\text { (TW) }\end{array}$ & $\begin{array}{l}\text { Ln (fold } \\
\text { change) }\end{array}$ & $P$-value & $q$-value & Significant \\
\hline C4H1 & Eucgr.C00065 & 731 & 121 & -1.80 & 0.4924 & 0.936 & No \\
\hline $\mathrm{C} 4 \mathrm{H} 2$ & Eucgr.J01844 & 1,397 & 887 & -0.45 & 0 & 0 & Yes \\
\hline 4CL & E. grandis ID & $\begin{array}{c}\text { Average } \\
\text { FPKM } \\
\text { (upright) }\end{array}$ & $\begin{array}{c}\text { Average } \\
\text { FPKM } \\
\text { (TW) }\end{array}$ & $\begin{array}{l}\text { Ln (fold } \\
\text { change) }\end{array}$ & $P$-value & q-value & Significant \\
\hline 4CL1 & Eucgr.C02284 & 948 & 605 & -0.45 & 0.4957 & 0.9352 & No \\
\hline 4CL2 & Eucgr.K00087 & 42 & 14 & -1.12 & 0.0008 & 0.0166 & Yes \\
\hline 4CL3 & Eucgr.B00135 & 0 & 0 & -0.21 & 0.7837 & 1 & No \\
\hline 4CL4 & Eucgr.B03468 & 0 & 0 & -0.19 & 0.8052 & 1 & No \\
\hline 4CL5 & Eucgr.B03502 & 0 & 0 & 0.91 & 0.2549 & 1 & No \\
\hline 4CL6 & Eucgr.B03942 & 4 & 6 & 0.30 & 0.4114 & 1 & No \\
\hline 4CL7 & Eucgr.B03943 & 9 & 7 & -0.32 & 0.36 & 1 & No \\
\hline 4CL8 & Eucgr.D02624 & 0 & 0 & 0.17 & 0.8219 & 1 & No \\
\hline 4CL9 & Eucgr.F03543 & 19 & 18 & -0.05 & 0.8875 & 1.0049 & No \\
\hline 4CL10 & Eucgr.G02758 & 0 & 0 & 0.00 & 0.3085 & 1 & No \\
\hline 4CL11 & Eucgr.G02879 & 0 & 0 & 0.00 & 0.3085 & 1 & No \\
\hline 4CL12 & Eucgr.K02927 & 1 & 0 & -0.31 & 0.6758 & 1 & No \\
\hline 4CL13 & Eucgr.K02929 & 5 & 4 & -0.27 & 0.486 & 1 & No \\
\hline
\end{tabular}




\begin{tabular}{|c|c|c|c|c|c|c|c|}
\hline HCT & E. grandis ID & $\begin{array}{c}\text { Average } \\
\text { FPKM } \\
\text { (upright) }\end{array}$ & $\begin{array}{c}\text { Average } \\
\text { FPKM } \\
\text { (TW) }\end{array}$ & $\begin{array}{l}\text { Ln (fold } \\
\text { change) }\end{array}$ & $P$-value & $q$-value & Significant \\
\hline HCT1 & Eucgr.F03972 & 0 & 1 & 0.81 & 0.2569 & 1 & No \\
\hline НСТ2 & Eucgr.F03973 & 0 & 0 & 0.00 & 0.1679 & 1 & No \\
\hline НСТ3 & Eucgr.F03974 & 0 & 0 & 0.00 & 0.1932 & 1 & No \\
\hline HCT4 & Eucgr.F03978 & 21 & 13 & -0.52 & 0.1272 & 1 & No \\
\hline HCT5 & Eucgr.J03126 & 288 & 240 & -0.18 & 0.8091 & 1.0055 & No \\
\hline СЗН & E. grandis ID & $\begin{array}{c}\text { Average } \\
\text { FPKM } \\
\text { (upright) }\end{array}$ & $\begin{array}{c}\text { Average } \\
\text { FPKM } \\
\text { (TW) }\end{array}$ & $\begin{array}{l}\text { Ln (fold } \\
\text { change) }\end{array}$ & $P$-value & q-value & Significant \\
\hline C3H1 & Eucgr.A02185 & 15 & 41 & 1.01 & 0.0015 & 0.0267 & Yes \\
\hline С3H2 & Eucgr.A02188 & 45 & 77 & 0.54 & 0.0902 & 0.4735 & No \\
\hline СЗНЗ & Eucgr.A02190 & 741 & 609 & -0.20 & 0.9166 & 1.0039 & No \\
\hline $\mathrm{C} 3 \mathrm{H} 4$ & Eucgr.G03199 & 316 & 16 & -2.99 & 0 & 0.0001 & Yes \\
\hline CCоAOMT & E. grandis ID & $\begin{array}{c}\text { Average } \\
\text { FPKM } \\
\text { (upright) }\end{array}$ & $\begin{array}{c}\text { Average } \\
\text { FPKM } \\
\text { (TW) } \\
\end{array}$ & $\begin{array}{l}\text { Ln (fold } \\
\text { change) }\end{array}$ & $P$-value & q-value & Significant \\
\hline CCoAOMT1 & Eucgr.I01134 & 750 & 487 & -0.43 & 0.6354 & 0.9808 & No \\
\hline ССоАОМТ2 & Eucgr.G01417 & 1,731 & 601 & -1.06 & 0.3313 & 0.8527 & No \\
\hline ССоАОМТЗ & Eucgr.B02687 & 0 & 0 & 0.00 & 1 & 1 & No \\
\hline CCoAOMT4 & Eucgr.C00924 & 0 & 0 & 0.00 & 1 & 1 & No \\
\hline CCoAOMT5 & Eucgr.C00925 & 0 & 0 & 0.00 & 0.049 & 1 & No \\
\hline СCoAOMT6 & Eucgr.C03667 & 0 & 0 & 0.00 & 1 & 1 & No \\
\hline ССоАOMT7 & Eucgr.C03668 & 0 & 0 & 0.00 & 1 & 1 & No \\
\hline ССоАОМТ8 & Eucgr.C03674 & 0 & 0 & 0.00 & 1 & 1 & No \\
\hline ССоАОМТ9 & Eucgr.C03680 & 0 & 0 & 0.00 & 0.1587 & 1 & No \\
\hline CCoAOMT10 & Eucgr.C03684 & 0 & 0 & -0.43 & 0.804 & 1 & No \\
\hline CCoAOMT11 & Eucgr.C03939 & 0 & 0 & 0.00 & 1 & 1 & No \\
\hline CCoAOMT12 & Eucgr.F04260 & 2 & 2 & 0.06 & 0.8883 & 1 & No \\
\hline ССоАОМТ13 & Eucgr.H04643 & 0 & 0 & 0.00 & 1 & 1 & No \\
\hline ССоAOMT14 & Eucgr.H04644 & 0 & 0 & 0.00 & 1 & 1 & No \\
\hline CCoAOMT15 & Eucgr.H04646 & 2 & 1 & -0.76 & 0.1257 & 1 & No \\
\hline ССоАОМТ16 & Eucgr.H04648 & 3 & 2 & -0.41 & 0.4372 & 1 & No \\
\hline CCoAOMT17 & Eucgr.H04650 & 0 & 0 & -0.49 & 0.6894 & 1 & No \\
\hline
\end{tabular}

\begin{tabular}{cccccccc}
\hline F5H & E.grandis ID & $\begin{array}{c}\text { Average } \\
\text { FPKM } \\
\text { (upright) }\end{array}$ & $\begin{array}{c}\text { Average } \\
\text { FPKM } \\
\text { (TW) }\end{array}$ & $\begin{array}{c}\text { Ln (fold } \\
\text { change) }\end{array}$ & P-value & q-value & Significant \\
\hline F5H1 & Eucgr.I02371 & 0 & 0 & 0.56 & 0.588 & 1 & No \\
F5H2 & Eucgr.J02393 & 1,854 & 1,362 & -0.31 & 0 & 0 & Yes \\
\hline
\end{tabular}




\begin{tabular}{|c|c|c|c|c|c|c|c|}
\hline COMT & E. grandis ID & $\begin{array}{c}\text { Average } \\
\text { FPKM } \\
\text { (upright) }\end{array}$ & $\begin{array}{c}\text { Average } \\
\text { FPKM } \\
\text { (TW) }\end{array}$ & $\begin{array}{l}\text { Ln (fold } \\
\text { change) }\end{array}$ & $P$-value & $q$-value & Significant \\
\hline COMT1 & Eucgr.A01397 & 2,908 & 2,648 & -0.09 & 0 & 0 & Yes \\
\hline COMT2 & Eucgr.A00759 & 0 & 0 & 0.00 & 0.1587 & 1 & No \\
\hline СОМТ3 & Eucgr.A01389 & 0 & 0 & 0.00 & 1 & 1 & No \\
\hline COMT4 & Eucgr.A01392 & 0 & 0 & 0.43 & 0.7602 & 1 & No \\
\hline COMT5 & Eucgr.A01394 & 0 & 0 & 0.00 & 1 & 1 & No \\
\hline COMT6 & Eucgr.A01395 & 0 & 0 & 0.00 & 0.0984 & 1 & No \\
\hline COMT7 & Eucgr.A01600 & 0 & 3 & 1.86 & 0.0035 & 1 & No \\
\hline COMT8 & Eucgr.A01795 & 0 & 0 & 0.57 & 0.6618 & 1 & No \\
\hline COMT9 & Eucgr.A01796 & 0 & 0 & 0.11 & 0.9446 & 1 & No \\
\hline COMT10 & Eucgr.A01797 & 0 & 0 & -0.70 & 0.7267 & 1 & No \\
\hline COMT11 & Eucgr.A01846 & 0 & 0 & -0.93 & 0.5881 & 1 & No \\
\hline COMT12 & Eucgr.A01863 & 0 & 0 & 0.00 & 1 & 1 & No \\
\hline COMT13 & Eucgr.A01865 & 0 & 0 & 0.00 & 1 & 1 & No \\
\hline COMT14 & Eucgr.A01867 & 0 & 0 & 0.00 & 0.1587 & 1 & No \\
\hline COMT15 & Eucgr.A01873 & 0 & 0 & 0.00 & 0.1587 & 1 & No \\
\hline COMT16 & Eucgr.A01874 & 0 & 0 & 0.00 & 1 & 1 & No \\
\hline COMT17 & Eucgr.A01875 & 0 & 0 & 0.00 & 0.2819 & 1 & No \\
\hline COMT18 & Eucgr.A01876 & 0 & 0 & -0.20 & 0.8689 & 1 & No \\
\hline COMT19 & Eucgr.A01877 & 0 & 0 & 0.00 & 0.2819 & 1 & No \\
\hline СОМТ20 & Eucgr.A01878 & 0 & 0 & 0.00 & 0.1587 & 1 & No \\
\hline СОМТ21 & Eucgr.A01880 & 0 & 0 & 0.00 & 1 & 1 & No \\
\hline СОМТ22 & Eucgr.A01881 & 0 & 0 & 2.07 & 0.1739 & 1 & No \\
\hline СOMT23 & Eucgr.A01884 & 0 & 0 & -0.44 & 0.6503 & 1 & No \\
\hline СОМТ24 & Eucgr.A02870 & 0 & 1 & 0.00 & 0.0317 & 1 & No \\
\hline COMT25 & Eucgr.B01744 & 1 & 2 & 0.36 & 0.4813 & 1 & No \\
\hline СОМТ26 & Eucgr.B01747 & 0 & 0 & -1.19 & 0.2973 & 1 & No \\
\hline СОMT27 & Eucgr.E01092 & 0 & 0 & 0.00 & 1 & 1 & No \\
\hline СОМТ28 & Eucgr.E03146 & 0 & 0 & 0.48 & 0.6355 & 1 & No \\
\hline СОМТ29 & Eucgr.E03148 & 0 & 0 & 1.29 & 0.2678 & 1 & No \\
\hline СОМТЗ & Eucgr.E03339 & 1 & 1 & 0.16 & 0.8419 & 1 & No \\
\hline СОМТ31 & Eucgr.E03341 & 0 & 1 & 0.47 & 0.5956 & 1 & No \\
\hline СОМТЗ2 & Eucgr.E03874 & 1 & 1 & 0.50 & 0.469 & 1 & No \\
\hline СОМТЗ3 & Eucgr.E03875 & 2 & 3 & 0.18 & 0.7015 & 1 & No \\
\hline СОМТ34 & Eucgr.E03877 & 0 & 0 & 0.00 & 1 & 1 & No \\
\hline СОМТЗ5 & Eucgr.F02623 & 17 & 6 & -1.06 & 0.0028 & 1 & No \\
\hline СОМТЗ6 & Eucgr.F02624 & 0 & 1 & 1.00 & 0.1213 & 1 & No \\
\hline СОМТ37 & Eucgr.F02625 & 0 & 0 & 0.00 & 0.1587 & 1 & No \\
\hline СОМТз8 & Eucgr.F03794 & 8 & 7 & -0.07 & 0.8654 & 1 & No \\
\hline СОМТ39 & Eucgr.G00017 & 0 & 0 & 0.00 & 1 & 1 & No \\
\hline COMT40 & Eucgr.G00020 & 0 & 0 & 0.00 & 0.1587 & 1 & No \\
\hline COMT41 & Eucgr.G01808 & 0 & 0 & 0.00 & 1 & 1 & No \\
\hline
\end{tabular}




\begin{tabular}{llllcccc} 
COMT42 & Eucgr.G01810 & 0 & 0 & 0.00 & 1 & 1 & No \\
COMT43 & Eucgr.H00347 & 0 & 0 & 0.00 & 0.2398 & 1 & No \\
COMT44 & Eucgr.H00348 & 0 & 0 & 0.00 & 1 & 1 & No \\
COMT45 & Eucgr.H00349 & 0 & 0 & 0.00 & 0.1587 & 1 & No \\
COMT46 & Eucgr.H00350 & 0 & 0 & 0.00 & 1 & 1 & No \\
COMT47 & Eucgr.H00351 & 0 & 0 & 0.00 & 1 & 1 & No \\
COMT48 & Eucgr.H00352 & 0 & 0 & 0.00 & 1 & 1 & No \\
COMT49 & Eucgr.H00353 & 0 & 0 & 0.00 & 1 & 1 & No \\
COMT50 & Eucgr.H00354 & 0 & 0 & 0.00 & 1 & 1 & No \\
COMT51 & Eucgr.H00356 & 0 & 0 & 0.00 & 1 & 1 & No \\
COMT52 & Eucgr.H03920 & 0 & 2 & 1.43 & 0.0272 & 1 & No \\
COMT53 & Eucgr.H03922 & 0 & 0 & 1.89 & 0.3266 & 1 & No \\
COMT54 & Eucgr.H03924 & 0 & 0 & 1.40 & 0.2023 & 1 & No \\
COMT55 & Eucgr.H03926 & 0 & 0 & -0.23 & 0.7667 & 1 & No \\
COMT56 & Eucgr.I02810 & 0 & 0 & 0.00 & 1 & 1 & No \\
COMT57 & Eucgr.K00041 & 0 & 0 & 0.00 & 1 & 1 & No \\
COMT58 & Eucgr.K00449 & 0 & 0 & 0.00 & 1 & 1 & No \\
COMT59 & Eucgr.K00949 & 0 & 0 & 0.00 & 1 & 1 & No \\
COMT60 & Eucgr.K00950 & 0 & 0 & 0.00 & 0.0786 & 1 & No \\
COMT61 & Eucgr.K00951 & 419 & 346 & -0.19 & 0.7944 & 1.0032 & No \\
COMT62 & Eucgr.K00953 & 0 & 0 & 1.02 & 0.4873 & 1 & No \\
COMT63 & Eucgr.K00954 & 0 & 0 & 0.40 & 0.7347 & 1 & No \\
COMT64 & Eucgr.K00955 & 6 & 0 & -3.18 & 0.0002 & 1 & No \\
COMT65 & Eucgr.K00956 & 0 & 0 & 0.11 & 0.9199 & 1 & No \\
COMT66 & Eucgr.K00957 & 1 & 5 & 1.29 & 0.014 & 1 & No \\
COMT67 & Eucgr.K01696 & 0 & 0 & 0.20 & 0.8643 & 1 & No \\
\hline
\end{tabular}

Average Average

CCR $\quad$ E.grandis ID FPKM $\quad$ FPKM $\begin{gathered}\text { Ln (fold } \\ \text { change) }\end{gathered}$-value $q$-value Significant

\begin{tabular}{llcccccc}
\hline CCR1 & Eucgr.J03114 & 518 & 389 & -0.29 & 0.7706 & 1.0033 & No \\
CCR2 & Eucgr.F03954 & 0 & 0 & 0.00 & 1 & 1 & No \\
CCR3 & Eucgr.B02222 & 30 & 38 & 0.24 & 0.4536 & 1 & No \\
CCR4 & Eucgr.C01240 & 132 & 36 & -1.30 & 0.0003 & 0.0062 & Yes \\
CCR5 & Eucgr.F03605 & 0 & 0 & 1.22 & 0.2592 & 1 & No \\
CCR6 & Eucgr.G00052 & 12 & 9 & -0.23 & 0.5315 & 1 & No \\
CCR7 & Eucgr.G02325 & 1 & 3 & 1.52 & 0.0069 & 1 & No \\
CCR8 & Eucgr.I01552 & 1 & 0 & -0.65 & 0.4757 & 1 & No \\
CCR9 & Eucgr.I01783 & 14 & 5 & -0.99 & 0.0051 & 1 & No \\
\hline
\end{tabular}




\begin{tabular}{|c|c|c|c|c|c|c|c|}
\hline CAD & E. grandis ID & $\begin{array}{c}\text { Average } \\
\text { FPKM } \\
\text { (upright) }\end{array}$ & $\begin{array}{c}\text { Average } \\
\text { FPKM } \\
\text { (TW) }\end{array}$ & $\begin{array}{l}\text { Ln (fold } \\
\text { change) }\end{array}$ & $P$-value & $q$-value & Significant \\
\hline CAD1 & Eucgr.G01350 & 37 & 40 & 0.07 & 0.8271 & 1.0018 & No \\
\hline CAD2 & Eucgr.H03208 & 109 & 68 & -0.47 & 0.1964 & 0.6745 & No \\
\hline CAD3 & Eucgr.D00468 & 0 & 0 & 0.00 & 1 & 1 & No \\
\hline CAD4 & Eucgr.D00471 & 0 & 0 & 0.00 & 1 & 1 & No \\
\hline CAD5 & Eucgr.D00472 & 0 & 0 & 0.00 & 1 & 1 & No \\
\hline CAD6 & Eucgr.D00473 & 0 & 0 & 0.00 & 1 & 1 & No \\
\hline CAD7 & Eucgr.D01086 & 0 & 0 & 0.00 & 1 & 1 & No \\
\hline CAD8 & Eucgr.D01087 & 0 & 0 & 0.00 & 1 & 1 & No \\
\hline CAD9 & Eucgr.D01088 & 0 & 0 & 0.00 & 0.2398 & 1 & No \\
\hline CAD10 & Eucgr.D01089 & 0 & 0 & 0.00 & 1 & 1 & No \\
\hline CAD11 & Eucgr.D01090 & 0 & 0 & 0.00 & 1 & 1 & No \\
\hline CAD12 & Eucgr.D01091 & 0 & 0 & 0.00 & 1 & 1 & No \\
\hline CAD13 & Eucgr.E01103 & 0 & 0 & 0.28 & 0.8117 & 1 & No \\
\hline CAD14 & Eucgr.E01104 & 0 & 1 & 1.20 & 0.101 & 1 & No \\
\hline CAD15 & Eucgr.E01105 & 2 & 2 & -0.38 & 0.4649 & 1 & No \\
\hline CAD16 & Eucgr.E01107 & 9 & 12 & 0.28 & 0.4266 & 1 & No \\
\hline CAD17 & Eucgr.E01108 & 1 & 4 & 1.29 & 0.0181 & 1 & No \\
\hline CAD18 & Eucgr.E01110 & 5 & 16 & 1.11 & 0.0002 & 1 & No \\
\hline CAD19 & Eucgr.E01115 & 0 & 2 & 2.16 & 0.0023 & 1 & No \\
\hline CAD20 & Eucgr.E01117 & 11 & 28 & 0.89 & 0 & 1 & No \\
\hline CAD21 & Eucgr.E01119 & 71 & 75 & 0.05 & 0.7962 & 1.0031 & No \\
\hline CAD22 & Eucgr.E02204 & 0 & 0 & 0.00 & 1 & 1 & No \\
\hline CAD23 & Eucgr.E02310 & 0 & 0 & 0.00 & 1 & 1 & No \\
\hline CAD24 & Eucgr.E02319 & 0 & 0 & 0.00 & 1 & 1 & No \\
\hline CAD25 & Eucgr.E02559 & 0 & 0 & 0.00 & 1 & 1 & No \\
\hline CAD26 & Eucgr.E02570 & 0 & 0 & 0.00 & 1 & 1 & No \\
\hline CAD27 & Eucgr.E02580 & 0 & 0 & 0.00 & 1 & 1 & No \\
\hline CAD28 & Eucgr.F01676 & 0 & 2 & 3.35 & 0.0066 & 1 & No \\
\hline CAD29 & Eucgr.F01677 & 0 & 1 & 1.64 & 0.1103 & 1 & No \\
\hline CAD30 & Eucgr.F01678 & 0 & 1 & 2.18 & 0.0675 & 1 & No \\
\hline CAD31 & Eucgr.F01679 & 0 & 1 & 3.47 & 0.093 & 1 & No \\
\hline CAD32 & Eucgr.F01680 & 0 & 1 & 0.00 & 0.0478 & 1 & No \\
\hline CAD33 & Eucgr.G02223 & 0 & 0 & 1.17 & 0.5009 & 1 & No \\
\hline CAD34 & Eucgr.H02411 & 0 & 0 & 0.00 & 1 & 1 & No \\
\hline CAD35 & Eucgr.H02412 & 0 & 0 & 0.00 & 1 & 1 & No \\
\hline CAD36 & Eucgr.H02414 & 0 & 0 & 0.00 & 1 & 1 & No \\
\hline CAD37 & Eucgr.H02415 & 0 & 0 & 0.00 & 0.1587 & 1 & No \\
\hline CAD38 & Eucgr.H02431 & 0 & 0 & 0.00 & 1 & 1 & No \\
\hline CAD39 & Eucgr.H02433 & 0 & 0 & 0.00 & 0.1587 & 1 & No \\
\hline CAD40 & Eucgr.H02434 & 0 & 0 & 0.00 & 1 & 1 & No \\
\hline CAD41 & Eucgr.H04903 & 10 & 20 & 0.67 & 0.0094 & 1 & No \\
\hline
\end{tabular}




\begin{tabular}{lllllcll} 
CAD42 & Eucgr.I00570 & 5 & 5 & 0.06 & 0.876 & 1 & No \\
CAD43 & Eucgr.I00571 & 0 & 0 & 0.00 & 0.1587 & 1 & No \\
CAD44 & Eucgr.I00572 & 0 & 0 & 0.00 & 0.1587 & 1 & No \\
CAD45 & Eucgr.I00573 & 0 & 0 & 0.00 & 1 & 1 & No \\
CAD46 & Eucgr.K01941 & 0 & 0 & 0.00 & 0.0786 & 1 & No \\
\hline
\end{tabular}

Significant differences are highlighted and average expression colouring is scaled within gene families. 
Table S8 Arabidopsis thaliana homologs significantly differentially expressed between tension wood and the upright control, in this study as well as in Populus (Andersson-Gunnerås et al., 2006)

\begin{tabular}{|c|c|c|c|}
\hline Arabidopsis ID & Description & $\begin{array}{c}\text { Shared } \\
\text { poplar/Eucalyptus? }\end{array}$ & Direction \\
\hline AT1G05010 & $\begin{array}{l}\text { EFE (ETHYLENE-FORMING ENZYME); 1- } \\
\text { aminocyclopropane-1-carboxylate oxidase }\end{array}$ & YES & UP \\
\hline AT1G17950 & $\begin{array}{l}\text { MYB52 (MYB DOMAIN PROTEIN 52); DNA binding / } \\
\text { transcription factor }\end{array}$ & YES & UP \\
\hline AT1G54100 & $\begin{array}{l}\text { ALDH7B4 (Aldehyde Dehydrogenase 7B4); 3-chloroallyl } \\
\text { aldehyde dehydrogenase/ oxidoreductase }\end{array}$ & YES & UP \\
\hline AT1G62990 & $\begin{array}{c}\text { KNAT7 (KNOTTED-LIKE HOMEOBOX OF } \\
\text { ARABIDOPSIS THALIANA 7); DNA binding / transcription } \\
\text { activator/ transcription factor }\end{array}$ & YES & UP \\
\hline AT2G01940 & nucleic acid binding / transcription factor/ zinc ion binding & YES & UP \\
\hline AT3G27330 & zinc finger (C3HC4-type RING finger) family protein & YES & UP \\
\hline AT3G43190 & $\begin{array}{l}\text { SUS4; UDP-glycosyltransferase/ sucrose synthase/ } \\
\text { transferase, transferring glycosyl groups }\end{array}$ & YES & UP \\
\hline АT3G47690 & zinc finger (GATA type) family protein & YES & UP \\
\hline AT5G27030 & FLA12 & YES & UP \\
\hline AT1G19300 & $\begin{array}{l}\text { PARVUS (PARVUS); polygalacturonate 4-alpha- } \\
\text { galacturonosyltransferase/ transferase, transferring glycosyl } \\
\text { groups / transferase, transferring hexosyl groups }\end{array}$ & YES & DOWN \\
\hline AT2G38060 & $\begin{array}{l}\text { PHT4;2 (PHOSPHATE TRANSPORTER 4;2); } \\
\text { carbohydrate transmembrane transporter/ inorganic } \\
\text { phosphate transmembrane transporter/ organic anion } \\
\text { transmembrane transporter/ sugar:hydrogen symporter }\end{array}$ & YES & DOWN \\
\hline AT3G04730 & IAA16; transcription factor & YES & DOWN \\
\hline
\end{tabular}




\begin{tabular}{|c|c|c|c|}
\hline AT3G06350 & $\begin{array}{c}\text { MEE32 (MATERNAL EFFECT EMBRYO ARREST 32); } \\
\text { 3-dehydroquinate dehydratase/ NADP or NADPH binding / } \\
\text { binding / catalytic/ shikimate 5-dehydrogenase }\end{array}$ & YES & DOWN \\
\hline AT3G21570 & unknown protein & YES & DOWN \\
\hline AT4G10270 & $\begin{array}{l}\text { MEE58 (MATERNAL EFFECT EMBRYO ARREST 58); } \\
\text { adenosylhomocysteinase/ copper ion binding }\end{array}$ & YES & DOWN \\
\hline AT4G13940 & $\begin{array}{l}\text { F5H (FERULIC ACID 5-HYDROXYLASE 1); ferulate 5- } \\
\text { hydroxylase/ monooxygenase }\end{array}$ & YES & DOWN \\
\hline AT4G36220 & protein binding & YES & DOWN \\
\hline AT5G07220 & remorin family protein & YES & DOWN \\
\hline AT5G23750 & pathogenesis-related thaumatin family protein & YES & DOWN \\
\hline AT5G37600 & ATEB1A; microtubule binding & YES & DOWN \\
\hline AT5G40020 & $\begin{array}{l}\text { PIP3 (PLASMA MEMBRANE INTRINSIC PROTEIN 3); } \\
\text { water channel }\end{array}$ & YES & DOWN \\
\hline AT5G60490 & TPR3 (TOPLESS-RELATED 3) & YES & DOWN \\
\hline AT1G06620 & 2-oxoglutarate-dependent dioxygenase, putative & NO & \\
\hline AT2G38080 & IRX12 (IRREGULAR XYLEM 12); laccase & NO & \\
\hline AT3G54810 & PLA IIIA (PATATIN-LIKE PROTEIN 6) & NO & \\
\hline AT3G54950 & wound-responsive family protein & NO & \\
\hline AT4G35100 & $\begin{array}{l}\text { ATBAG3 (ARABIDOPSIS THALIANA BCL-2- } \\
\text { ASSOCIATED ATHANOGENE 3); protein binding }\end{array}$ & NO & \\
\hline AT5G14230 & ATGSR1; copper ion binding / glutamate-ammonia ligase & NO & \\
\hline
\end{tabular}

For each ID, the description is provided as well as whether the direction of expression in tension wood relative to the upright control was shared between Eucalyptus and Populus.

\section{Andersson-Gunnerås S, Hellgren JM, Björklund S, Regan S, Moritz T, Sundberg B. 2003.}

Asymmetric expression of a poplar ACC oxidase controls ethylene production during gravitational induction of tension wood. Plant Journal 34: 339-349. 
Table S9 CAZymes upregulated in tension wood and their relative expression in seven tissues of

\section{Eucalyptus grandis}

\begin{tabular}{|c|c|c|c|c|c|c|c|c|c|c|}
\hline Gene ID & Arabidopsis hits & Protein name & CAZyme & $\begin{array}{c}\text { Young } \\
\text { leaf }\end{array}$ & Shoot tips & $\begin{array}{c}\text { Mature } \\
\text { leaf }\end{array}$ & flowers & roots & phloem & $\begin{array}{c}\text { Immature } \\
\text { xylem }\end{array}$ \\
\hline Eucgr.H00343 & AT1G684701 & & GT47 & $0 \%$ & $0 \%$ & $0 \%$ & $0 \%$ & $0 \%$ & $7 \%$ & $93 \%$ \\
\hline Eucgr.F00232 & AT4G333301 & GUX2, PGSIP3 & GT8 & $1 \%$ & $3 \%$ & $2 \%$ & $3 \%$ & $5 \%$ & $11 \%$ & $75 \%$ \\
\hline Eucgr.C03199 & АТ3G431901 & SUS4 & GT4 & $12 \%$ & $9 \%$ & $8 \%$ & $14 \%$ & $2 \%$ & $10 \%$ & $46 \%$ \\
\hline Eucgr.A00510 & AT2G381501 & & GT32 & $0 \%$ & $0 \%$ & $0 \%$ & $0 \%$ & $66 \%$ & $0 \%$ & $34 \%$ \\
\hline Eucgr.J01374 & AT3G293201 & & GT35 & $2 \%$ & $7 \%$ & $2 \%$ & $15 \%$ & $17 \%$ & $27 \%$ & $30 \%$ \\
\hline Eucgr.I01147 & AT1G497101 & FUCTB, FUT12 & GT10 & $19 \%$ & $16 \%$ & $15 \%$ & $11 \%$ & $0 \%$ & $9 \%$ & $29 \%$ \\
\hline Eucgr.H00536 & AT3G178801 & HIP, TDX & GT41 & $12 \%$ & $11 \%$ & $9 \%$ & $14 \%$ & $4 \%$ & $25 \%$ & $25 \%$ \\
\hline Eucgr.K00865 & AT4G152401 & & GT31 & $11 \%$ & $24 \%$ & $14 \%$ & $13 \%$ & $0 \%$ & $15 \%$ & $24 \%$ \\
\hline Eucgr.F03658 & AT1G557401 & AtSIP1, SIP1 & GH36 & $23 \%$ & $13 \%$ & $10 \%$ & $9 \%$ & $2 \%$ & $23 \%$ & $20 \%$ \\
\hline Eucgr.E01169 & AT4G194201 & & CE13 & $16 \%$ & $5 \%$ & $30 \%$ & $10 \%$ & $1 \%$ & $19 \%$ & $20 \%$ \\
\hline Eucgr.B00354 & AT1G238701 & ATTPS9, TPS9 & GT20 & $18 \%$ & $20 \%$ & $12 \%$ & $9 \%$ & $13 \%$ & $9 \%$ & $18 \%$ \\
\hline Eucgr.B02686 & AT1G680201 & ATTPS6, TPS6 & GT2O & $16 \%$ & $24 \%$ & $13 \%$ & $15 \%$ & $14 \%$ & $8 \%$ & $10 \%$ \\
\hline Eucgr.F01855 & AT1G451301 & BGAL5 & GH35 & $19 \%$ & $13 \%$ & $27 \%$ & $19 \%$ & $1 \%$ & $11 \%$ & $9 \%$ \\
\hline Eucgr.I01697 & AT3G273301 & & GT92 & $23 \%$ & $19 \%$ & $22 \%$ & $21 \%$ & $1 \%$ & $7 \%$ & $6 \%$ \\
\hline Eucgr.B02118 & AT5G288401 & GME & & $12 \%$ & $17 \%$ & $12 \%$ & $25 \%$ & $0 \%$ & $29 \%$ & $6 \%$ \\
\hline Eucgr.B00859 & АT3G180801 & BGLU44 & GH1 & $22 \%$ & $18 \%$ & $21 \%$ & $22 \%$ & $0 \%$ & $12 \%$ & $5 \%$ \\
\hline
\end{tabular}

Data for relative expression is available on EucGeNIE (www.eucgenie.org). Colour intensity indicates

relative tissue expression for each gene (white, 0; red, 100\%) in each of the seven listed tissues and

organs. 